Hydraulic Engineering Repository

Ein Service der Bundesanstalt für Wasserbau

Winterwerp, Johan C.; Wanga, Zheng Bing; Van Braeckel, Alexander; Van Holland, Gijsbert; Kösters, Frank

Man-induced regime shifts in small estuaries - II: a comparison of rivers

Verfügbar unter / Available at:

https://hdl.handle.net/20.500.11970/100668

Vorgeschlagene Zitierweise / Suggested citation:

Winterwerp, Johan C.; Wanga, Zheng Bing; Van Braeckel, Alexander; Van Holland, Gijsbert; Kösters, Frank (2013): Man-induced regime shifts in small estuaries - II: a comparison of rivers. In: Ocean Dynamics Vol. 63 (11/12). S. 1293-1306. 
Erstveröffentlichung in Ocean Dynamics 63 (2013), S. 1293-1306.

Für eine korrekte Zitierbarkeit ist die Seitennummerierung

der Originalveröffentlichung für jede Seite kenntlich gemacht.

S. 1293

\title{
Man-induced regime shifts in small estuaries-II: a comparison of rivers
}

Johan C. Winterwerpa,b \& Zheng Bing Wanga, ${ }^{\mathrm{b}}$ \& Alexander van Braeckelc $\&$ Gijsbert van Holland ${ }^{\mathrm{d}}$ \& Frank Kösterse

\author{
a Deltares (formerly WL|Delft Hydraulics), PO Box 177, 2600 MH Delft, The Netherlands \\ b Environmental Fluid Mechanics, Delft University of Technology, PO Box 5048, 2600 GA Delft, The Netherlands, e-mail: \\ han.winterwerp@deltares.nl \\ c Research Institute for Nature and Forest, Kliniekstraat 25, 1070 Brussels, Belgium \\ d IMDC, Coveliersstraat 15, Berchem, 2600 Antwerp, Belgium \\ e Bundesanstalt für Wasserbau, Wedeler Landstr. 157, 22559 Hamburg, Germany
}

Received: 21 February 2013 /Accepted: 15 October 2013 /Published online: 13 November 2013

Responsible Editor: Rockwell Geyer

This article is part of the Topical Collection on Physics of Estuaries and Coastal Seas 2012

This is Part II of two papers onman-induced regime shifts in small, narrow, and converging estuaries, with focus on the interaction between effective hydraulic drag, fine sediment import, and tidal amplification, induced by river engineering works, e.g., narrowing and deepening. Paper I describes a simple linear analytical model for the tidal movement in narrow, converging estuaries and a conceptual model on the response of tidal rivers to river engineering works. It is argued that such engineering works may set in motion a snowball effect bringing the river into an alternative steady state. Part II analyses the historic development in tidal range in four rivers, e.g., the Elbe, Ems, Loire, and Scheldt, all in northwest Europe; data are available for many decades, up to a century. We use the analytical model derived in Part I, showing that the effective hydraulic drag in the Ems and Loire has decreased considerably over time, as anticipated in Part I. We did not find evidence that the Upper Sea Scheldt is close to its tipping point towards hyperturbid conditions, but risks have been identified. In the Elbe, tidal reflections against the profound step in bed level around Hamburg seem to have affected the tidal evolution in the last decades. It is emphasized that the conceptual picture sketched in these papers is still hypothetical and needs to be validated, for instance through hind-cast modeling of the evolution of these rivers. This will not be an easy task, as historical data for a proper calibration of the models required are scarce.

Keywords: Tidal amplification . Hydraulic drag. Dispersion equation . Regime shift. Elbe. Ems . Loire. Scheldt 


\section{Autorenfassung}

Winterwerp, Wang, van Braeckel, van Holland, Kösters: Man-induced regime shifts in small estauries-II: a comparison of rivers, 2013

\section{Introduction}

In many European rivers, tidal ranges have increased dramatically in the course of the twentieth century, and some rivers (e.g., Loire and Ems) have evolved into hyperturbid systems. Though it is recognized that large-scale engineering works, such as reclamations, embankments, and deepening, have caused these tidal amplifications and shifts towards a hyperturbid state, the underlying mechanisms are not yet fully understood. It is the aim of the present paper to enhance our understanding of these processes. This is done in two papers, analyzing the longterm historic evolution of the tide in four rivers, e.g., the Elbe, Ems, Loire, and Scheldt Rivers. This analysis is presented in the current Part II, using the linear analytical model and relevant nondimensional parameters, derived and discussed in Part I of this paper. In Part I, we also hypothesize how a reduction in river-induced flushing and increase in flood dominancy may pump in large amounts of fine sediments (mud), enhancing the effects of river deepening on tidal amplification.

Our methodology is as follows. We collected data on the historical interventions within these four rivers and on the

Winterwerp, Wang, van Braeckel, van Holland, Kösters:

Man-induced regime shifts in small estauries-II: a comparison of rivers.

S. 1294 Zeitschrift Ocean Dynamics 63 (2013), S. 1293-1306.

evolution of the tidal range. Where available, we use the asymmetry from the measured ratio of rising and falling tide. Some data go back to the late $1800 \mathrm{~s}$. We are very grateful to a large number of people who have contributed to this data collection. These data have then been elaborated as follows:

- We have collected and analyzed all available data on historical interventions in the various rivers, starting from the time that the first tidal data are available.

- The convergence length $L_{b}$ of the river has been established by plotting the width of the flowcarrying cross section against length. In some cases, $\mathrm{L}_{b}$ showed a profound kink midriver, in which case we apply two different values of $L_{b}$. Apart for the Elbe and Loire, $L_{b}$ remained more or less constant over the period over which tidal data are available.

- When available, the width of the intertidal area was established. If not, an estimate was made on the basis of Google Earth images-note that in those cases, $\Delta \mathrm{b}$ is quite small and does not contribute too much to the tidal dynamics, hence errors in these are not too important.

- Water depths were provided in various formats, such as the depth of the river's thalweg. Ideally, the hydraulic radius is to be used, but the mean depth $h=A_{c} / b_{c}$ is a good approximation in shallow rivers, which has been used throughout the study.

- Water depths are generally given with respect to some reference level. The mean water depth therefore had to be corrected for the tidal range, assuming the mean slope is not too large. As a 


\section{Autorenfassung}

Winterwerp, Wang, van Braeckel, van Holland, Kösters: Man-induced regime shifts in small estauries-II: a comparison of rivers, 2013

rule of thumb, we presume that the mean water level is found midway between high and low water.

- The river is subdivided into subsections in between the tidal stations. For each subsection, characteristic water depth and convergence length are determined.

- The imaginary wave number $\mathrm{k}_{\mathrm{i}}$ is determined from the data for each subsection by dividing the measured tidal ranges of two adjacent tidal stations being $\Delta x$ apart: $\left(a_{2} / a_{1}=\exp \left\{k_{i} \Delta x\right\}\right)$.

- In times when bathymetrical and tidal data are not synchronized, either of the two has been interpolated, obtaining a consistent set of synchronous data.

- Imaginary wave number and bathymetrical data were made dimensionless, obtainingкi and $\Lambda$, as discussed in Part I of this paper.

- These data points are plotted in a $\kappa_{\mathrm{i}}-\Lambda$ e diagram; every pair of these parameters represents the measured bathymetry and tidal amplification/damping of one subsection of the river for one particular time period. Then, the analytical solution (equ. 10b of Part I) was fitted through these data points by tuning the friction parameter $r$ * Note that we assume infinitely long rivers and do not account for possible reflections against a weir, or otherwise, unless stated otherwise.

- For some rivers, we studied the effects of tidal reflections in a schematic way; a more thorough approach requires a different model.

- Step 10 yields the time evolution of $r$ *, e.g., the change in effective hydraulic drag over time. Fromr*, theChézy coefficient is established, for which the flow velocity is needed. For this, we use the analytical solution given by equ. (12) in Part I.

- Finally, we determinethe tidal asymmetry. Inmost cases, data on asymmetry are given, and we do not need to use the proxy $\gamma$, defined in Part I.

- For the Elbe and Scheldt rivers, an indicative assessment of the contributions of tidal reflections to the tidal amplifications is made.

This procedure is applied in chapters 2 through 5 for the Elbe, Ems, Loire, and Scheldt Rivers, respectively. The results of these analyses are compared in chapter 6 , where the results are also interpreted with respect to the conceptual picture proposed in Part I.

\section{The Elbe River-Germany}

The Elbe River originates in the Karkonosze mountains of the Czech Republic and flows through Germany over $630 \mathrm{~km}$ passing the city of Hamburg (km620; largestGerman seaport) at about 110 $\mathrm{km}$ from the mouth at Cuxhaven (km 729, North Sea). At km 588 (Geesthacht), i.e., $32 \mathrm{~km}$ upestuary of Hamburg, a weir was built in 1960. The river downstream of Geesthacht is known as the Tideelbe, and the stretch downestuary of Hamburg is subject of the study in this section. The mean annual freshwater discharge ranges between 200 and 3,600 m33 s, with a mean value of about 700 $\mathrm{m}^{3} / \mathrm{s}$. The mouth of the estuary is characterized by a narrow deep channel and a very wide tidal flat (Hakensand, Medem Sand, Nordergründe) up to $2 \mathrm{~m}$ above the lowest astronomical tide (LAT); see also Admiralty Chartno. 3261. The total width of the mouth is about $15 \mathrm{~km}$. The width of the deep channel is in the range of 1,500 to 3,000 $\mathrm{m}$. The cross-sectional area below LAT of the deep channel at the mouth is in the range of about 20,000 to $40,000 \mathrm{~m} 2$. In this chapter, we study the evolution of 


\section{Autorenfassung}

Winterwerp, Wang, van Braeckel, van Holland, Kösters: Man-induced regime shifts in small estauries-II: a comparison of rivers, 2013

the Elbe River between $\mathrm{km} 620$ (Hamburg) and km 718 (10 km upestuary of Cuxhaven), i.e., a river stretch of $98 \mathrm{~km}$; the river widens rapidly down-estuary of km 718.

The following design depths for navigation were implemented (Kappenberg and Fanger 2007):

- 1936-1950, $10 \mathrm{~m}$ (note that these engineering works commenced already at the turn of the nineteenth to twentieth century)

Winterwerp, Wang, van Braeckel, van Holland, Kösters:

Man-induced regime shifts in small estauries-II: a comparison of rivers. Zeitschrift Ocean Dynamics 63 (2013), S. 1293-1306.

- $1957-1962,11 \mathrm{~m}$

- $1964-1969,12 \mathrm{~m}$

- $1975-1978,13.5 \mathrm{~m}$

- $1998-2000,14.4 \mathrm{~m}$

Note that we do not have data before 1940, though the Portal Tideelbe (e.g., "Veränderungen am Fluss") states that in 1859 the fairway was deepened to $-5.9 \mathrm{~m}$, whereas from 1910 a depth of 8-10 $m$ has been maintained. As discussed in the "Introduction," this does not mean that the mean depth of the Elbe has increased by $4.4 \mathrm{~m}$ since 1936, as the fairway does not cover the entire river's cross section, e.g., Fig. 1. Also, since the 1930s some intertidal area was lost as well by embankments and reclamation works, and some tributaries were closed by a sluice or weir. Major reclamations and embankment works were carried mainly in the lower part of the Elbe River in response to the 1962 and 1976 floods. Note that as a result of the fairway deepening, the river bed depicts a step of about $14 \mathrm{~m}$ around Hamburg (Kappenberg and Fanger 2007).

Longitudinal bathymetrical data over the period 1995- 2010 presented by the Portal Tideelbe (1999) show that the riverbed is characterized by bed forms which can be fairly steep with lengths of the order of $100 \mathrm{~m}$ and heights varying from a few decimeters to about $2 \mathrm{~m}$. However, the data do not clearly depict a substantial change over time in the character of these bed forms. Hence, we may expect not too much change in effective hydraulic drag by reducing bed from heights. Figure 2 presents the evolution of the tidal range along the Elbe River, as presented by Weilbeer et al. (2011), based on historical data at 16 stations.

Figure 2 shows that initially, i.e., in the beginning of the century, the tide was damped over the entire estuary. However, after the 1970s, a considerable amplification of the tide up-estuary of km $\sim 680$ (between Glückstadt and Freiburg) is observed. Only up-estuary of Hamburg, the tide is damped again. This irregular behavior is likely to be attributed to a kink in the convergence of the river around $\mathrm{km}$ 680. In the outer estuary, i.e., down-estuary of $\mathrm{km} \mathrm{680,} \mathrm{a} \mathrm{convergence} \mathrm{length} \mathrm{of} 93$ $\mathrm{km}$ is found, whereas in the inner estuary, $\mathrm{L}_{b}=30 \mathrm{~km}$ is found. It is postulated that this fairly un- 


\section{Autorenfassung}

Winterwerp, Wang, van Braeckel, van Holland, Kösters: Man-induced regime shifts in small estauries-II: a comparison of rivers, 2013

common distribution is the result of human interventions, e.g., embanking and reclamation, in particular following the 1962 and 1976 floods. There are indications that the convergence of the inner river was increased in the course of the $1970 \mathrm{~s}$ ( $\mathrm{L}_{\mathrm{b}}$ from 40 to $30 \mathrm{~km}$ ), though the data are not too accurate. Figure 2 suggests that the tidepenetrates theriver up to the weir at Geesthacht since the 1970s.

In the following, we distinguish between the inner and outer estuary, with a transition around km 680. Because of a lack of sufficiently detailed data, we treat the outer and inner estuary as two different, but homogeneous, parts of the river. Then, based on the data of Fig. 2, the variation in the imaginary wave number ki can be assessed for the two river sections.

Next, tidal and bathymetrical data are made dimensionless, using the definitions of equ. (9) of Part I, and the friction coefficient $r^{*}$ has been tuned to match the linear analytical model with the observations, assuming an infinitely long river. The results are presented in Fig. 3, showing a profound difference in the behavior of the outer and inner estuary. Amplification in the outer estuary has not changed too much over time (see also Fig. 2), and the dimensionless friction coefficient $r^{*}$ does not vary too much. On the contrary, $\mathrm{r}^{*}$ varies largely in the inner estuary, reducing from about 2.6 to 0.9 .

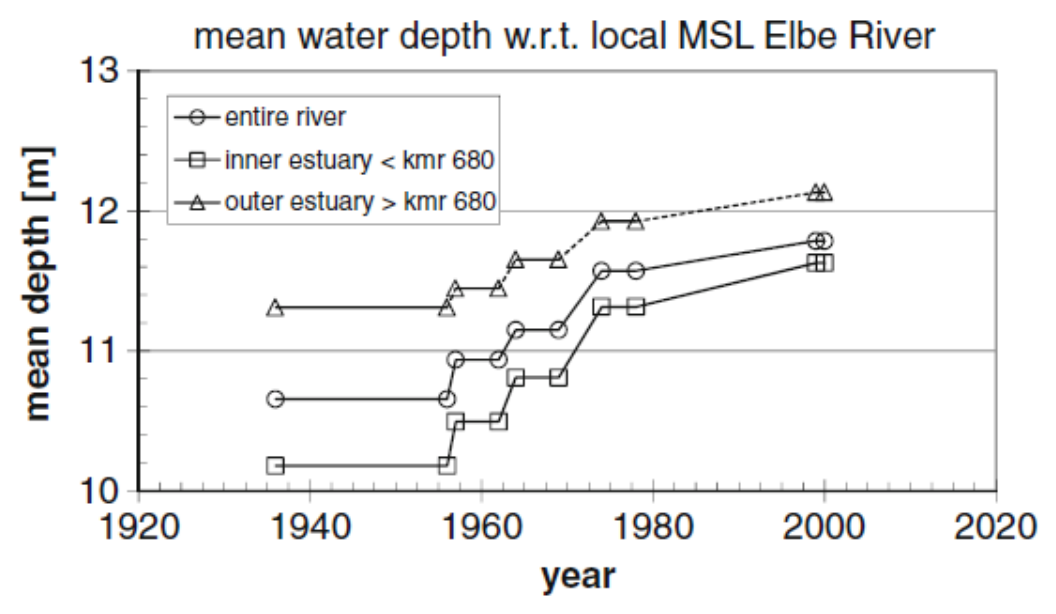

Fig. 1 Variation in mean water depth in inner estuary $(\mathrm{km}$ 620-680) and outer estuary $(\mathrm{km}$ 680-718) 


\section{Autorenfassung}

Winterwerp, Wang, van Braeckel, van Holland, Kösters: Man-induced regime shifts in small estauries-II: a comparison of rivers, 2013

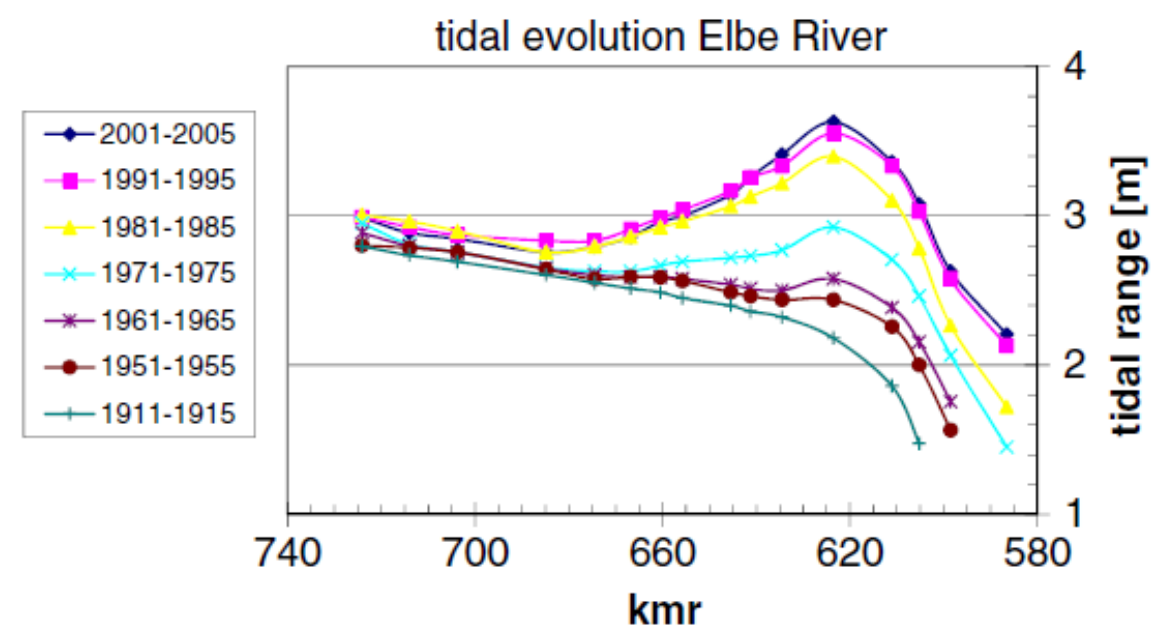

Fig. 2 Evolution of tidal range in the Elbe River (after BAW 2012); Hamburg is around km 620

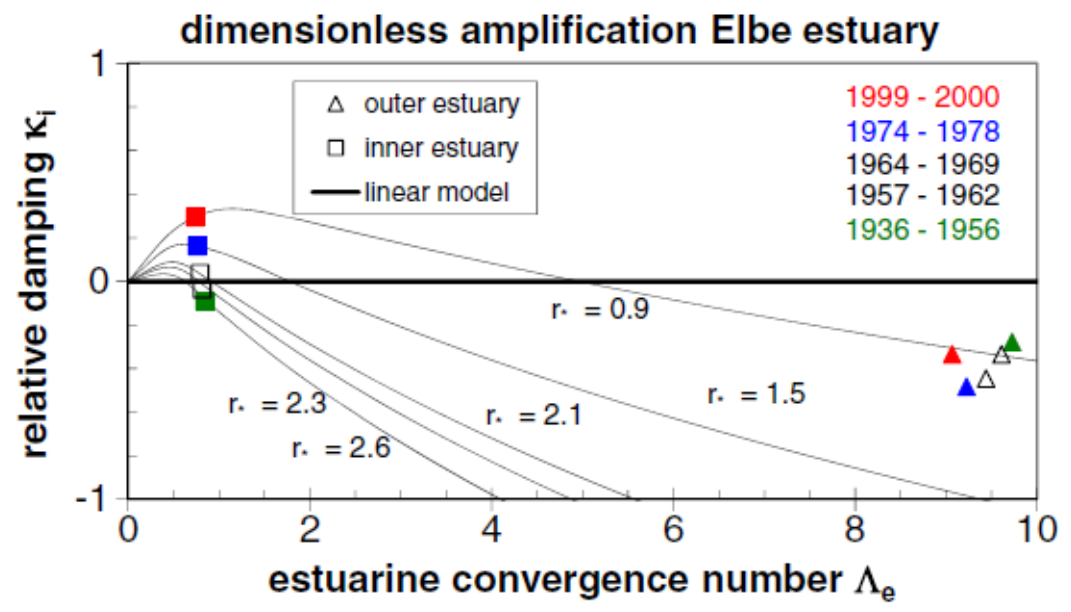

Fig. 3 Dimensionless imaginary wave number $\kappa_{\mathrm{i}}$ as a function of the estuarine convergence number $\Lambda_{e}$, and fitted solution of the analytical model (infinitely long river) by tuning $r^{*}$

Winterwerp, Wang, van Braeckel, van Holland, Kösters:

Man-induced regime shifts in small estauries-II: a comparison of rivers.

Zeitschrift Ocean Dynamics 63 (2013), S. 1293-1306.

The Chézy coefficients established from the various $r$ * values of Fig. 3 are presented in Fig. 4. The values in the outer estuary are high and more or less constant over time. On the other hand, in the inner estuary, $C$ is found to increase largely up to values of about $70 \mathrm{~m}^{1 / 2} / \mathrm{s}$. As this increase cannot be attributed to a reduction in bed forms, this large increase in $\mathrm{C}$ should be attributed to other effects. 


\section{Autorenfassung}

Winterwerp, Wang, van Braeckel, van Holland, Kösters: Man-induced regime shifts in small estauries-II: a comparison of rivers, 2013

The high Chézy values in the outer estuary are in agreement with the high suspended particulate matter (SPM) values in this part of the river and the very muddy intertidal areas (e.g., Kappenberg and Fanger 2007). Weilbeer et al. (2011) needed similar smooth roughness values in a threedimensional hydrodynamic model to simulate the tidal propagation properly.

However, SPM concentrations are consistently low in the inner estuary, hardly exceeding $50 \mathrm{mg} / \mathrm{l}$ (e.g., Kappenberg and Fanger 2007), suggesting rough bed conditions. These low values are (partly) to be attributed to the sedimentmanagement in the river around Hamburg, wherelarge amounts of fines are removed from the system, keeping the harbor basins accessible. Indeed, in this part of the river,Weilbeer and Klöpper (Weilbeer et al. 2011) needed larger roughness values to simulate the tidal propagation properly, though they had difficulty in properly simulating tidal amplification and phase with uniform roughness values. So why does the analytical linear model predict such large increases in $\mathrm{C}$ values in the inner estuary, while assuming an infinitely long estuary?

The answer may be found in the large discontinuity in bed level in the Elbe, with a step of about 14 $\mathrm{m}$ at km 620 (Kappenberg and Fanger 2007). This discontinuity is likely to induce reflections, increasing the tidal range, an effect not accounted for in the analysis of Fig. 4. Therefore, a zero-order assessment of this step in bed level wasmade by assuming full reflection at km 620 (Hamburg). Furthermore, the analysis of the data suggests that in the course of the 1970s, the convergence of the inner estuary has been increased by river works. Therefore, we present results for $\mathrm{L}_{b}=30$ and $40 \mathrm{~km}$, using the mean depths of Fig. 1, e.g., Fig. 5.

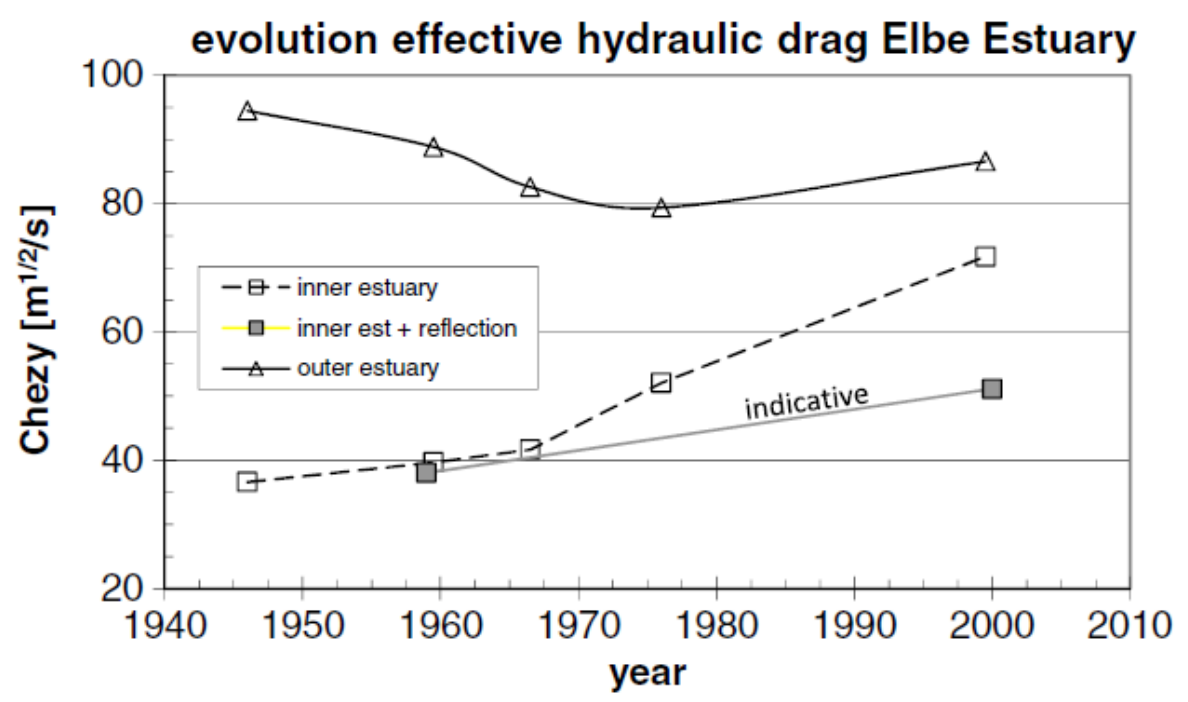

Fig. $4 \quad$ Evolution of Chézy coefficient with time, based on the r* values established from Fig. 3; also, indicative results are presented accounting for tidal reflections in the river 


\section{Autorenfassung}

Winterwerp, Wang, van Braeckel, van Holland, Kösters: Man-induced regime shifts in small estauries-II: a comparison of rivers, 2013

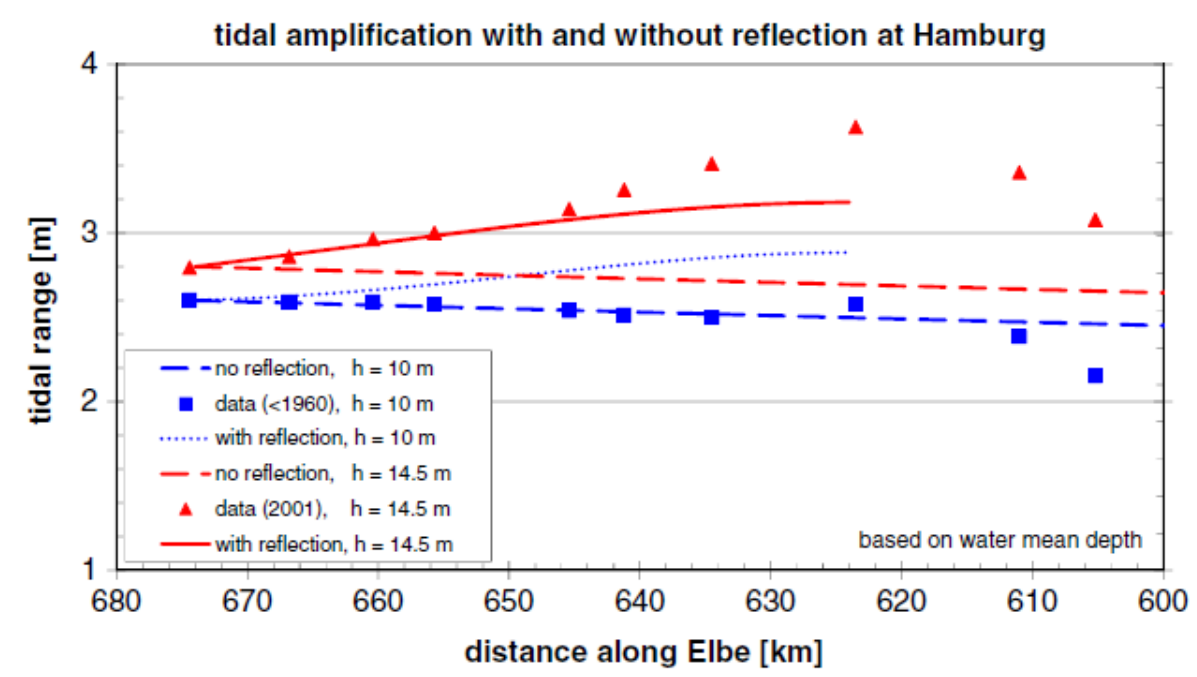

Fig. 5 Computation of tidal amplitude for pre- 1970 conditions $\left(\mathrm{L}_{b}=40 \mathrm{~km}, \mathrm{r}=0.004 \mathrm{~m} / \mathrm{s}-\right.$ broken line ) and post -1970 conditions ( $\mathrm{L}_{\mathrm{b}}=30 \mathrm{~km}, \mathrm{r}=0.003$ - solid line); Hamburgat $\mathrm{km} 620$

The pre-1960 data could only be reproduced assuming an infinitely long river and a fairly rough bed $(r=0.004)$. The results in Fig. 5 suggest that tidal reflections around kmr 620 did not play a role then. The 2000 data could be reproduced, assuming a very smooth bed, as shown in Fig. 4. However, if we presume "sandy" conditions, i.e., not too low $r$ values, we need to account for reflections of the tide at kmr 620, as shown in Fig. 5.

From these observations, we anticipate that the increase in effective bed roughness in the upper estuary (Fig. 4) is probably largely overestimated, as part of the amplification should be attributed to reflections. However, it is not likely that full reflection takes place at Hamburg. The increase of Chézy from 38 to $51 \mathrm{~m}^{1 / 2} / \mathrm{s}$ can only partly (e.g., for $2-5 \mathrm{~m}^{1 / 2} / \mathrm{s}$ ) be explained by the deepening itself. Hence, the indicative increase in C of Fig. 4 must be attributed to either a too large simplification of the tidal conditions in the Elbe River, or to decreases in effective hydraulic drag be a reduction in bed forms (e.g., steepness) and/or a small increase in SPM values. A further elaboration of this hypothesis requires detailed numerical modeling, accounting for the actual changes in bathymetry at great detail.

Finally, we have computed the proxy $\gamma$ for the tidal asymmetry (Part I, equ. 19). Figure 6 shows that the outer estuary seems ebb-dominant, whereas the inner estuary seems 


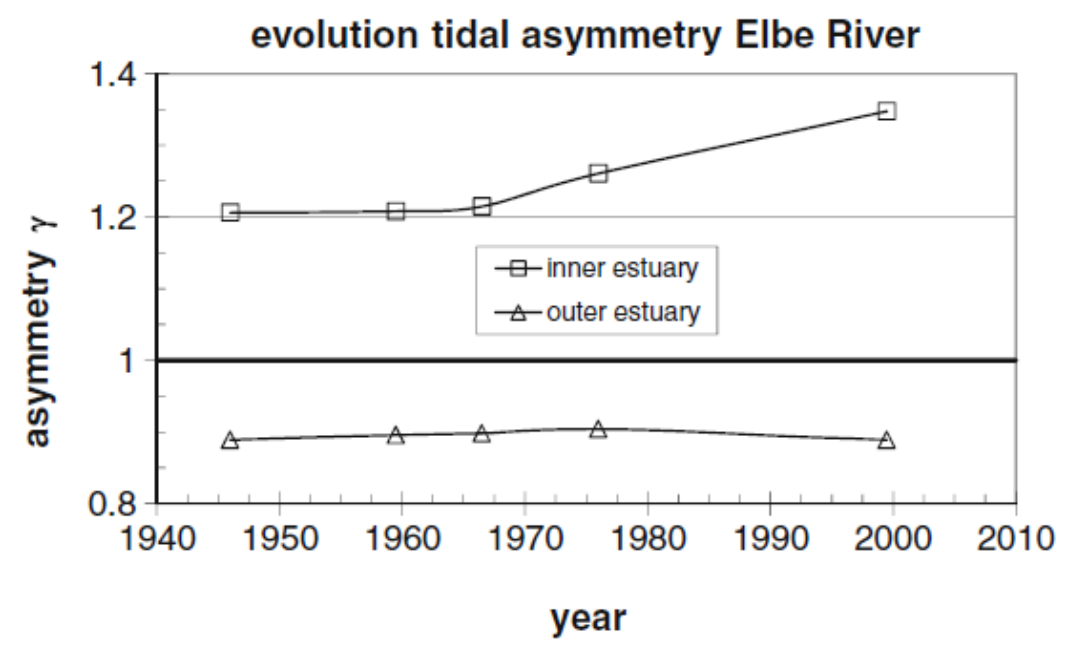

Fig. 6 Evolution of tidal asymmetry, based on the $\gamma$-proxy defined in Part I

Winterwerp, Wang, van Braeckel, van Holland, Kösters:

Man-induced regime shifts in small estauries-II: a comparison of rivers.

Zeitschrift Ocean Dynamics 63 (2013), S. 1293-1306.

to be flood-dominant. This disjunctive behavior is to be attributed to the considerable intertidal area, still present in the outer estuary. This behavior is corroborated by the Bundesanstalt fürWasserbau (BAW2012) showing that, near Hamburg, the ratio of rising to falling tide amounts to about $3: 4$, hence profoundly flood-dominant conditions. Apparently, the river flow is (still) so large that large quantities of fine sediment cannot accumulate in the water column up-estuary of the salinity front. In other words, a secondary turbidity maximum (ETM2, e.g., Part I) cannot be formed (e.g., Weilbeer et al. 2011). This role of the river flow is corroborated by the observations that maintenance dredging requirements in the Port of Hamburg increase with decreasing river flow (Kappenberg and Fanger 2007).

\section{The Ems River-Germany}

The Ems River (Unterems) is about $53 \mathrm{~km}$ long from the weir at Herbrum to Emden, flowing through Germany. Emden is located more or less at the border between Germany and The Netherlands, but more important, almost at the mouth of the river, where it flows into the wide and shallow Ems-Dollard estuary. This river is renowned for its large suspended sediment concentrations, with values up to 30-40 g/l over most of the upper part of the river (e.g., Talke et al. 2009). Though detailed data do not exist, it is believed that the regime shift of this river was set in motion in the early 1990s (de Jonge 2000). These high concentrations are found well beyond the region of salinity intrusion, and move to and fro with the tide. These conditions are characteristic for the secondary estuarine turbidity maximum (ETM2) discussed in Part I of this study. Also, profound layers of 


\section{Autorenfassung}

Winterwerp, Wang, van Braeckel, van Holland, Kösters: Man-induced regime shifts in small estauries-II: a comparison of rivers, 2013

fluid mud are found, in particular, around slack water and neap tide (e.g., Schrottke and Bartholomä 2008). Currently, the total mass of suspended solids amounts to about 1 Mton, while yearly about 1.5 Mton of solids is removed from the Ems River by dredging. For further details on the river, the reader is referred to Krebs and Weilbeer (2005).

The data of four tidal stations are analyzed in this paper, e.g., Emden (km 53), Leerort (km 28), Papenburg ( $\mathrm{km} \mathrm{13),} \mathrm{and} \mathrm{Herbrum} \mathrm{(} \mathrm{km} \mathrm{0)}$. The Ems River is engineered mainly to serve the Jos L. MeyerWharfs in Papenburg, i.e., in case cruise ships are to be sailed down-estuary, the Ems River is dredged.

The Ems River is characterized by a profound tapering. The overall convergence length of the river amounts to about $19 \mathrm{~km}$, whereas for the stretches between Emden-Leerort Lb $\approx 32 \mathrm{~km}$, LeerortPapenburg $L_{b} \approx 27 \mathrm{~km}$, and Papenburg-Herbrum $L_{b} \approx 33 \mathrm{~km}$. In the following, we refer to these three sections as $\mathrm{E}-\mathrm{L}, \mathrm{L}-\mathrm{P}$, and $\mathrm{P}-\mathrm{H}$. The apparent discrepancy of the overall convergence length and those of three smaller stretches of the river is attributed to some jigsaw patterns in the river's plan form. In our analysis, we used the larger values per subsection.

An overview of the various interventions in the river was sum marized in Vroom et al. (2012), based on information from Rijkswaterstaat and the BAW. The evolution in mean water depths for the three stretches E-L, L-P, and P-H is presented in Fig. 7, where the target depths have been averaged to obtain mean values for these sections. The river bed is dredged to these design depths only when a big cruise ship has to be conveyed down-river fromthe MeyerWharfs- on average, this is done once a year.

Around 1961, in the upper part of the river $(\mathrm{P}-\mathrm{H})$, groins have been constructed, narrowing the river locally, but no reclamation of intertidal area took place anymore after 1940. At present, the intertidal area is virtually zero, and the small areas remaining after embanking of the river have silted up considerably. In our analysis, we assume an intertidal area of $10 \%$, which is so small that it does not notably affect the tidal characteristics in the river. There are no indications that the convergence length of the river has changed much over the period of our analyses.

The response of the tidal range to these interventionsis presented in Fig. 8, in conjunction with an overview of the human interventions(Vroom et al. 2012). Figure 8 suggests that the response of the tidal range to the various interventions is not instantaneous, but takes considerable time to attain equilibrium-Fig. 7 suggests a time scale of at least one to two decades. We will address this further below. Finally, it is noted that the tidal range at Herbrum (and to a lesser extend Papenburg) becomes highly irregular, which is to be attributed to yearly variations in river flow. In a next phase of the study, we will address the role of river flow further.

From Fig. 8, the imaginary wave number ki (amplification factor) was determined. For the trajectory Papenburg- Herbrum, the highly irregular behavior hampers a proper analysis, and we therefore ignore the behavior of the tide along this trajectory. Moreover, this reach must be affected by reflections against Herbrum weir (see below). It is noted that for both reaches, $\mathrm{E}-\mathrm{L}$ and $\mathrm{L}-\mathrm{P}$, the data 


\section{Autorenfassung}

Winterwerp, Wang, van Braeckel, van Holland, Kösters: Man-induced regime shifts in small estauries-II: a comparison of rivers, 2013

show that amplification of the tide is observed from 1995 on-before the tidal wave was still damped, though only slightly (see also Fig. 9).

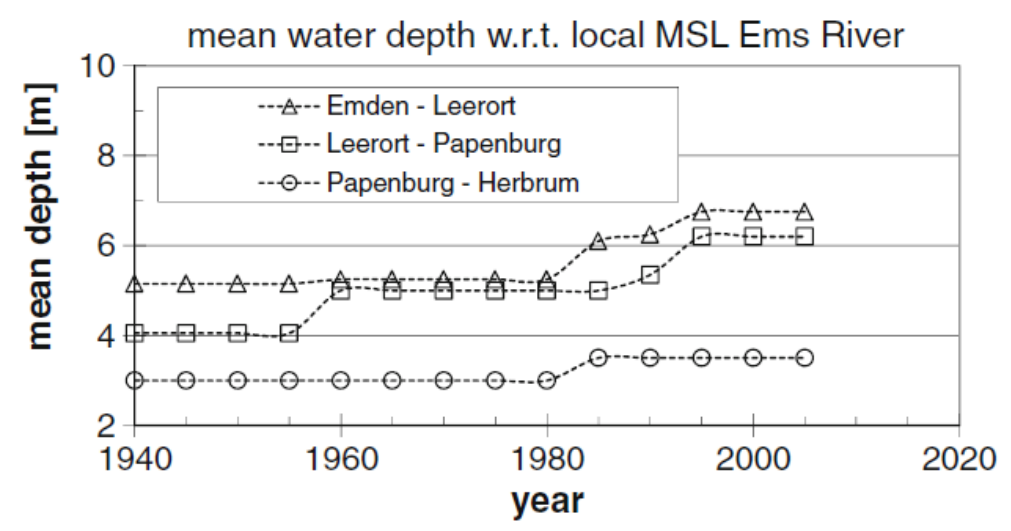

Fig. 7 Evolution of mean design water depths in Ems River for threetrajectories (water depth with respect to mean sea level at Emden)

Winterwerp, Wang, van Braeckel, van Holland, Kösters:

Man-induced regime shifts in small estauries-II: a comparison of rivers.

S. 1298 Zeitschrift Ocean Dynamics 63 (2013), S. 1293-1306.

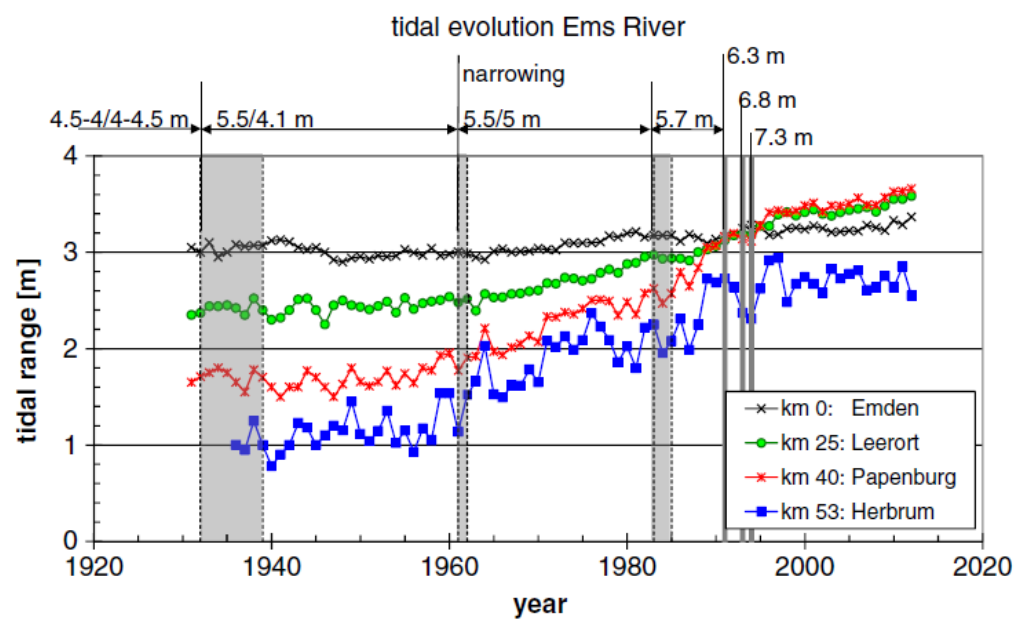

Fig. 8 Evolution of measured mean tidal range in Ems River and summary of interventions5.5/4.1 m indicates a design depth of $5.5 \mathrm{~m}$ over the Emden-Leerort reach, and $4.5 \mathrm{~m}$ over the Leerort-Papenburg reach; design depth Papenburg-Herbum reachwas $3 \mathrm{~m}$ till 1980, and then $3.5 \mathrm{~m}$ (data collected by Vroom et al. 2012) 


\section{Autorenfassung}

Winterwerp, Wang, van Braeckel, van Holland, Kösters: Man-induced regime shifts in small estauries-II: a comparison of rivers, 2013

Next, the imaginary wave number is made dimensionless with the convergence length $L_{b}$ and plotted against the estuarine convergence number $\Lambda_{\mathrm{e}}$ in Fig. 9. Then, the linear solution (equ. 10b, Part I) is fitted through the data by tuning the roughness parameter $r$. Again, we assume an infinitely long estuary, or in other words, we assume that the effects of reflection against the weir at Herbrum down-estuary of Papenburg are small.

Figure 9 shows a profound evolution in tidal characteristics; time runs diagonally from bottomright to top-left. It is remarkable that for instance in the period 1960-1980, the damping over the Leerort-Papenburg reach decreased considerably, though $\Lambda_{\mathrm{e}}$ did not change. This is most likely due to slow (morphological) responses of the river to the engineering works carried out earlier.

For a more physical interpretation, the roughness parameter $r$ * has to be converted to the Chézy coefficient C. For this conversion, we use the computed amplitude of the flow velocity (equ. 12, Part I) in conjunction with measured tidal amplitudes.

Figure 10 suggests that up to the 1960s, the Ems River was quite rough, with Chézy values in the E$\mathrm{L}$ reach of about $60 \mathrm{~m}^{1 / 2} / \mathrm{s}$, which is typical for a sandy river bed. Further upstream, in the L-P reach, Chézy values as low as $40 \mathrm{~m}^{1 / 2} / \mathrm{s}$ are found. We are not certain that these low values are entirely correct, but if so, they may be indicative for steep bed forms (dunes), such as observed for instance in the Elbe and Weser Rivers (e.g., Van Rijn 1993). The gradual increase in Chézy coefficient between the 1960s and 1980s may than be attributed to a gradual increase in water depth in (morphodynamic) response to earlier engineering works, and/or a decrease in dune heights and steepness owing to ongoing dredging. However, from the 1990s onward, the Ems River became more and more infamous for its very high suspended sediment concentrations with hyperconcentrated values towards the end of the twentieth century. Today, suspended sediment concentrations measure several $10 \mathrm{~g} / \mathrm{l}$, e.g., in Talke et al. (2009). The very large values of $\mathrm{C}=80-90 \mathrm{~m}^{1 / 2} / \mathrm{s} \mathrm{can}$ only be explained from the profound buoyancyinduced damping by the large suspended sediment concentrations (e.g., Part I).

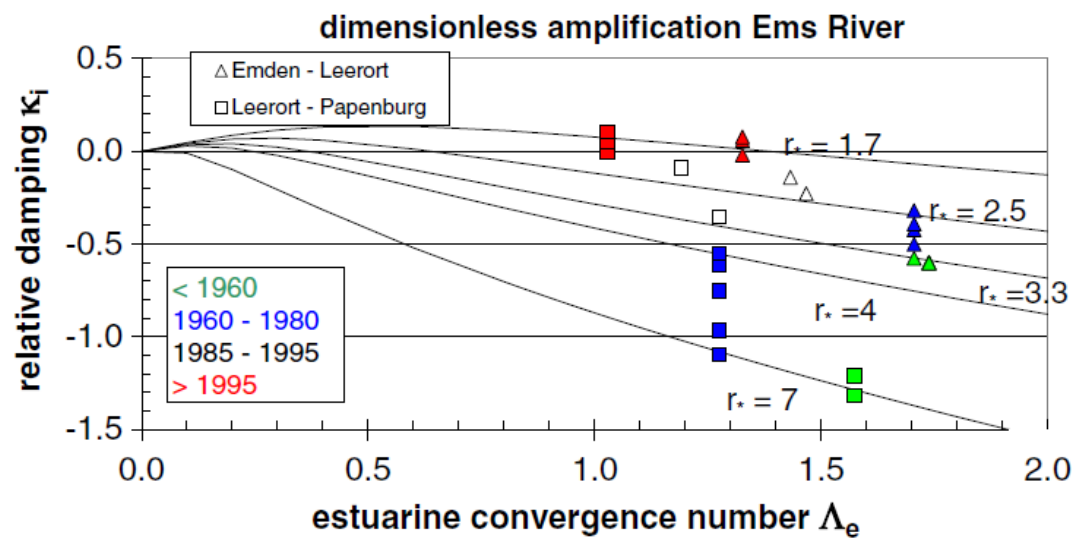

Fig. 9 Fits of linear solution to observed data through tuning of roughness parameter in $\kappa_{\mathrm{i}}-\Lambda_{\mathrm{e}}$ diagram 


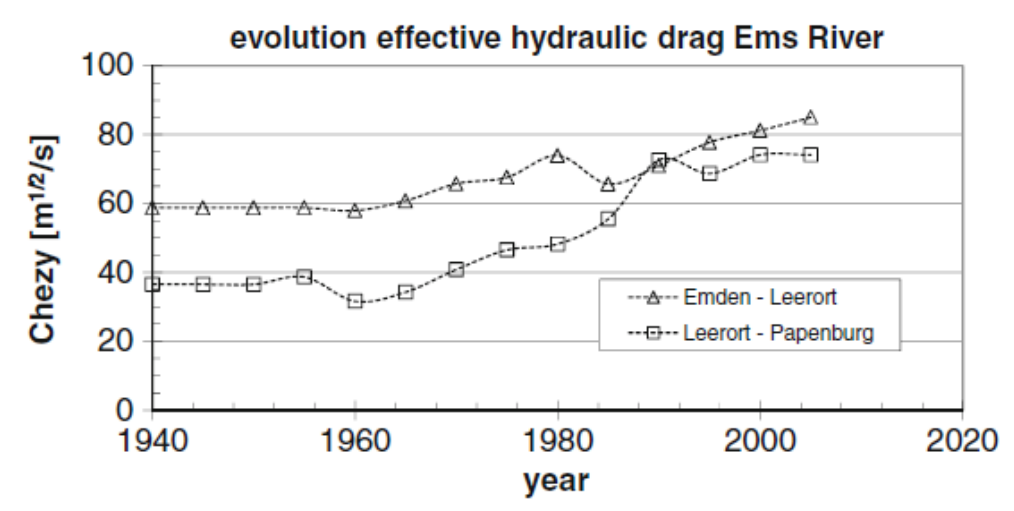

Fig.10 Evolution of effective hydraulic drag (Chézy coefficient) with time

upstream, in the L-P reach, Chézy values as low as $40 \mathrm{~m}^{1 / 2} / \mathrm{s}$ are found. We are not certain that these low values are entirely correct, but if so, they may be indicative for steep bed forms (dunes), such as observed for instance in the Elbe and Weser Rivers (e.g., Van Rijn 1993). The gradual increase in Chézy coefficient between the 1960s and 1980s may than be attributed to a gradual increase in water depth in (morphodynamic) response to earlier engineering works, and/or a decrease in dune heights and steepness owing to ongoing dredging. However, from the 1990s onward, the Ems River became more and more infamous for its very high suspended sediment concentrations with hyperconcentrated values towards the end of the twentieth century. Today, suspended sediment concentrations measure several $10 \mathrm{~g} / \mathrm{l}$, e.g., in Talke et al. (2009). The very large values of $\mathrm{C}=80-90 \mathrm{~m}^{1 / 2} / \mathrm{s}$ can only be explained from the profound buoyancyinduced damping by the large suspended sediment concentrations (e.g., Part I).

As we have ignored the effects of tidal reflections against the weir at Herbrum, we expect that the Chézy values, in particular for the trajectory Leerort-Papenburg, are a bit overestimated and should be lower by a value of about $5-10 \mathrm{~m}^{1 / 2} / \mathrm{s}$. In particular, we have argued in Part I that the effect of tidal reflections becomes apparent over a larger stretch of the river, owing to an increase in roughness length with reducing hydraulic drag.

Next, the evolution in celerity along the Ems River is elaborated. We use the results of an analysis by Herrling and Niemeyer (2008) on the tidal propagation (travel time) between Leerort and Papaneburg in the late 1930s and 2006. Using the estuarine convergence number $\Lambda_{\mathrm{e}}$ and the roughness parameter $r$ * obtained from calibration of the linear model against the observed evolution in tidal range, the celerity computed with the linear model (equ. 14a, Part I) can be compared to the numerical results by Herrling and Niemeyer (2008). Figure 11 shows that the linear model predicts the evolution in travel time very well, though only two points in time are available, of course.

Finally, the asymmetry parameter $\gamma$ (e.g., equ. 20, Part I) is determined, using the measured values of water depth and tidal amplitude. The results are presented in Fig. 12, showing 


\section{Autorenfassung}

Winterwerp, Wang, van Braeckel, van Holland, Kösters: Man-induced regime shifts in small estauries-II: a comparison of rivers, 2013

Winterwerp, Wang, van Braeckel, van Holland, Kösters:

Man-induced regime shifts in small estauries-II: a comparison of rivers.

Zeitschrift Ocean Dynamics 63 (2013), S. 1293-1306.

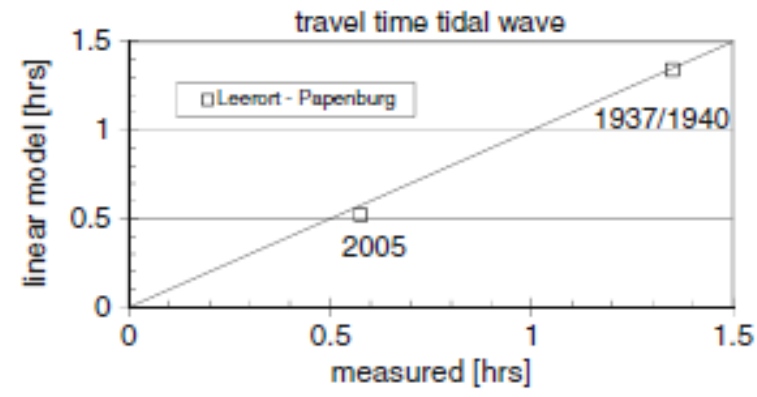

Fig.11 Measured and computed travel timetidal wave along Ems River in 1940 and 2005"measured" data follow from a detailed analysis of the tidal evolution with a threedimensional numerical model (Herrling and Niemeyer 2008)

that over the entire data range, $\gamma>1$, i.e., flood-dominant conditions prevail, as anticipated in Part I for rivers with little or no intertidal area. The tidal asymmetry remains almost constant for the E-L trajectory of the river, but $\gamma$ for the L- $\mathrm{P}$ trajectory grows continuously after the deepening of the 1960 s, exceeding the asymmetry in the E-L range beyond the 1980 s. Also, the data suggest a profound flood dominance of the tide, though no information is available on the historic development (Vroom et al. 2012).

\section{The Loire River - France}

The Loire estuary from St Nazaire to Nantes measures about $53 \mathrm{~km}$. In this paper, we study the development of the tide in the Loire River from Paimboeuf (at km 14), which is located at the transition between the inner and outer estuary, where the estuary converges strongly. Hence, we study a stretch of about $40 \mathrm{~km}$. Mean freshwater flow rates range from 400 to $700 \mathrm{~m}^{3} / \mathrm{s}$, with a maximum of up to $5,000 \mathrm{~m}^{3} / \mathrm{s}$. The data discussed below have been collected in a study by Deltares commissioned by GIP (Briere et al. 2012), summarizing reports by Sogreah (2006), in particular Sogreah's report on the historical development of the Loire River.

In the early decades of the twentieth century, the Loire River was heavily modified. Figure 13 shows the canalization of the river up to La Martinière ( $\mathrm{km} \mathrm{37),} \mathrm{realized} \mathrm{in} \mathrm{the} \mathrm{first} \mathrm{decade.} \mathrm{This}$ canalization took place up to Nantes ( $\mathrm{km} \mathrm{53),} \mathrm{but} \mathrm{unfortunately,} \mathrm{no} \mathrm{maps} \mathrm{are} \mathrm{available} \mathrm{for} \mathrm{the} \mathrm{sec-}$ tion La Martinière-Nantes. The effect on the river's convergence (e.g., Lb) has not been so large; it is estimated that $L_{b}$ decreased from about 25 to $30 \mathrm{~km}$ in the beginning of the twentieth century to 


\section{Autorenfassung}

Winterwerp, Wang, van Braeckel, van Holland, Kösters: Man-induced regime shifts in small estauries-II: a comparison of rivers, 2013

about $21 \mathrm{~km}$ today. However, the intertidal area has decreased considerably from $\mathrm{b}^{*}=2$ to about 1.1 at present. Note that between $\mathrm{km} 32$ and 36, the river is very narrow, owing to an array of massive groins in the river's bend.

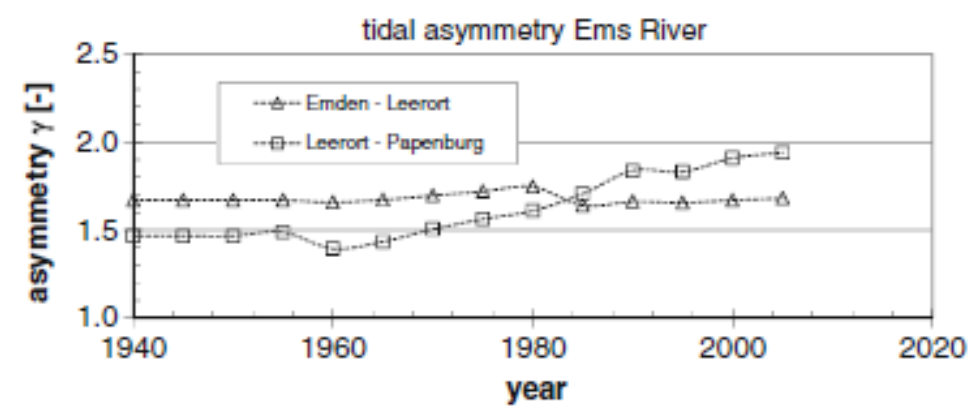

Fig.12 Evolution of tidal asymmetry parameter with time

A decade later, e.g., 1910-1920, the so-called Bassin Marée was formed by large-scale extractions of sand from the river upstream of Nantes.We were not able to find detailed data on these withdrawals, but bathymetrical data suggests that the river bed was affected and lowered well beyond Nantes. Up to Nantes, the river is deepened by almost $5 \mathrm{~m}$. However, also many tens of kilometers up-estuary, the river deepened by many meters. It is likely that this deepening was only partly the direct result of dredging and sand extraction and that also morphological responses to the large changes in the river's plan form contributed to the deepening. For our analysis, though, the actual causes of the bed level changes are not relevant.

The evolution in water depth is presented in Fig. 14, showing a profound deepening in the early twentieth centuryand then again in the 1960s (Sogreah 2006). As discussed above, the early/mid 1900 deepening may have been the byproduct of the significant narrowing of the river in the first decade of the twentieth century (Fig. 13) and the subsequent formation of the Bassin Marée, increasing the river's tidal prism. However, we have no further data on these interventions and their implications.

The data received concern values of the thalweg with respect to local chart datum CM96, which is about $3.6 \mathrm{~m}$ below mean sea level at the mouth of the estuary (St Nazaire). It is estimated that MSL is about $0.3 \mathrm{~m}$ higher at Nantes, and the subsequentslope in MSL along the river has been accounted for in Fig. 14. From an analysis of the data of the present bathymetry, it is estimated that the thalweg lies about 1-2 m below the mean water depth (cross section divided by river width), e.g., Briere et al. (2012). In the following, we assume that the depth of Fig. 14 should be raised by $1 \mathrm{~m}$ for the years 1900-1947 and by $2 \mathrm{~m}$ for the years thereafter-this has been accounted for in the analyses below. 


\section{Autorenfassung}

Winterwerp, Wang, van Braeckel, van Holland, Kösters: Man-induced regime shifts in small estauries-II: a comparison of rivers, 2013

Note that the data of Fig. 14 are neither very accurate nor complete, so the analysis in this section cannot be too accurate, in particular the developments later in the twentieth century-more detailed data have been requested.

The measured evolution in tidal amplitude is presented in Fig. 15, showing huge amplifications of the tide in the first half of the twentieth century. Though at a smaller rate, the tidal amplitude continues to increase after the $1950 \mathrm{~s}$, at Nantes for instance by $0.7 \mathrm{~m}$. In the following, we focus on the inner river (e.g., up-estuary of Paimboeuf) and subdivide the river further to the four tidal stations along the river (Paimboeuf-

Winterwerp, Wang, van Braeckel, van Holland, Kösters:

Man-induced regime shifts in small estauries-II: a comparison of rivers. Zeitschrift Ocean Dynamics 63 (2013), S. 1293-1306.

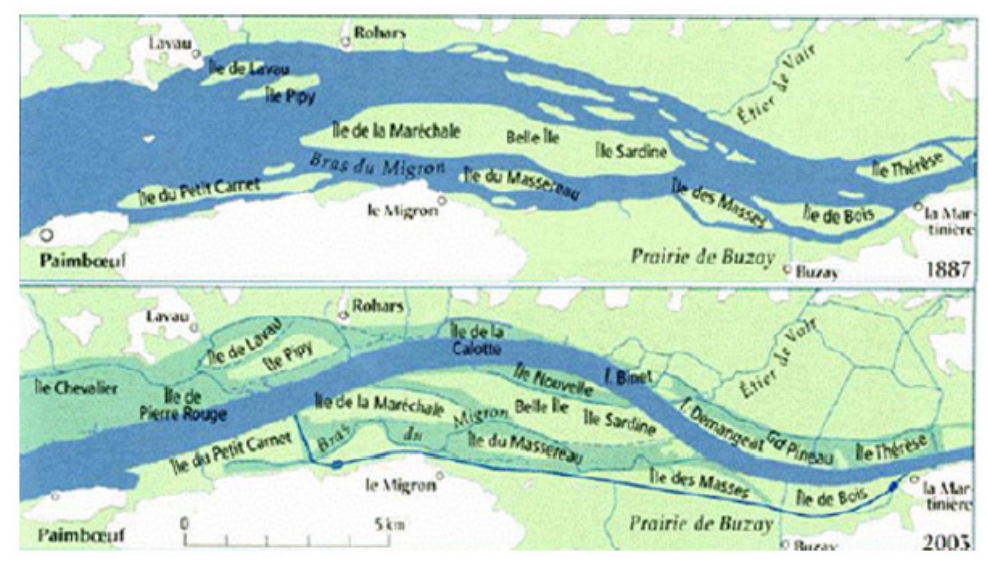

Fig. 13 Canalization of the Loire River in 1903-1910

Cordemais, Cordemais-La Martiniere, LaMartiniere-Nantes, e.g., stretches of 13, 10, and $11 \mathrm{~km}$, respectively).

The evolution of the dimensionless imaginary wave number $\kappa_{\mathrm{i}}$ is established as a function of $\Lambda_{\mathrm{e}}$, the results of which are shown in Fig. 16. Huge changes occurred in the early twentieth century, no doubt because of the canalization of the river in that period. From 1940 onwards, $\kappa_{\mathrm{i}} \approx 0$, i.e., the tide is no longer damped in the Loire River. Note that the trend is very strong and consistent in the early twentieth century, but thereafter becomes a bit erratic. We believe that this is due to inaccuracies in the data, both in the bathymetrical information and in the tidal data.

Next, the linear model for an infinitely long tidal river (equ. 10b, Part I) is fitted to the measured tidal damping by tuning the effective dimensionless roughness coefficient $r$ to the data, e.g., Fig. 


\section{Autorenfassung}

Winterwerp, Wang, van Braeckel, van Holland, Kösters: Man-induced regime shifts in small estauries-II: a comparison of rivers, 2013

16. From the fitted $r$ * values, the effective Chézy coefficient can be obtained, using the observed (corrected) water depths and computed flow velocities (e.g., equ. 12, Part I).

Figure 17 shows the variation in Chézy coefficient throughout the twentieth century for the three river sections in the Loire. The Chézy coefficient in the first part of the estuary (PaimboeufCordemais) has basically remained constant over time at a value between 60 and $70 \mathrm{~m}^{1 / 2} / \mathrm{s}$. However, in the upper two sections, the Chézy coefficient has increased from around 30-40 up to 60-70 $\mathrm{m}^{1 / 2} / \mathrm{s}$. The major changes took place in the period before 1940 , when the estuary was considerably narrowed, and the tidal prism increased by the creation of the Bassin Marée. Note that the higher values are not very high, in particular not for a very muddy system as the Loire-fluid mud is generally observed between Cordemais and Nantes (Sogreah 2006). However, the increase in C is consistent with the results for the Ems River and with our estimates in Part I, Section 2, of that paper.

Because of inaccuracies in the available tidal data, it is not possible to obtain proper trends in the $\gamma$ parameter (proxy for tidal asymmetry) with the analytical model. However, all information reveals that the tide in the Loire has become highly asymmetrical. Whereas the tide at the mouth of the Loire River (observations at Donge, e.g., Sogreah, 2006) is almost symmetrical, near Nantes, the tide rises in about $4 \mathrm{~h}$, whereas falling tide is about $50 \%$ longer. These observations are corroborated by numerical simulations by Sogreah (2006).

Note that the asymmetry in flow velocity is largely affected by the freshwater river flow, which may be large. Hence, the effects of tidal asymmetry (both in peak velocity and internal

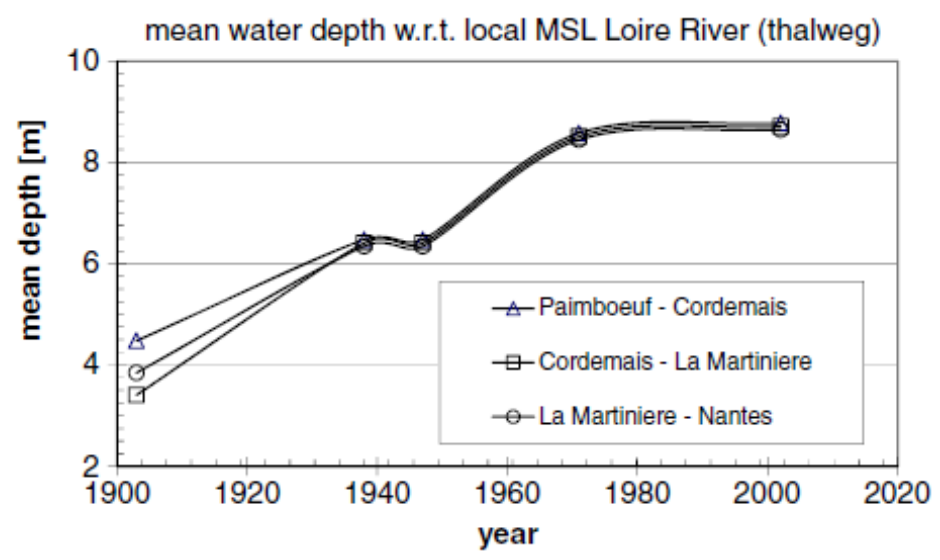

Fig.14 Evolution of water depth (thalweg) with respect to local mean water level (data convergence: chart datum CM96 is $3.6 \mathrm{~m}$ belowMSL at St Nazaire) 


\section{Autorenfassung}

Winterwerp, Wang, van Braeckel, van Holland, Kösters: Man-induced regime shifts in small estauries-II: a comparison of rivers, 2013

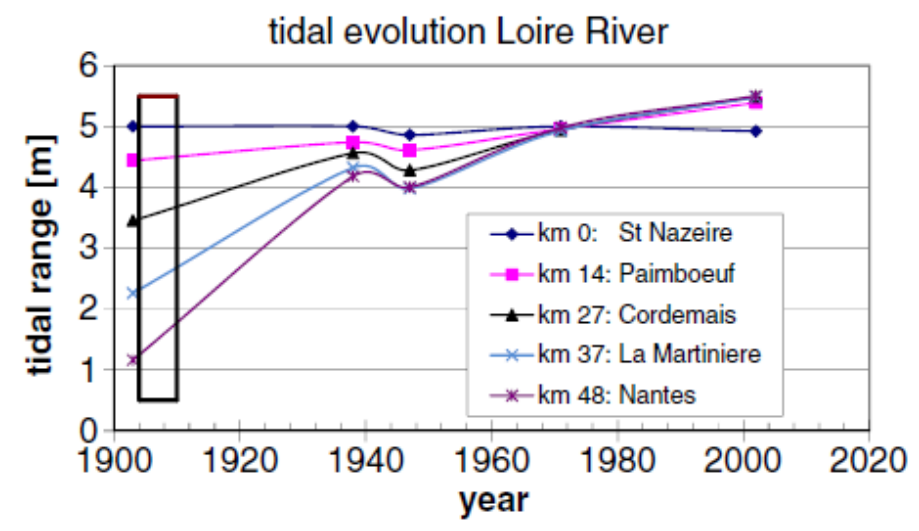

Fig.15 Evolution of the tidal amplitude along the Loire River; the black box represents the period of river narrowing (e.g., Fig. 13). The irregular behavior around 1940 is likely caused by inaccurate data

Winterwerp, Wang, van Braeckel, van Holland, Kösters:

Man-induced regime shifts in small estauries-II: a comparison of rivers.

Zeitschrift Ocean Dynamics 63 (2013), S. 1293-1306.
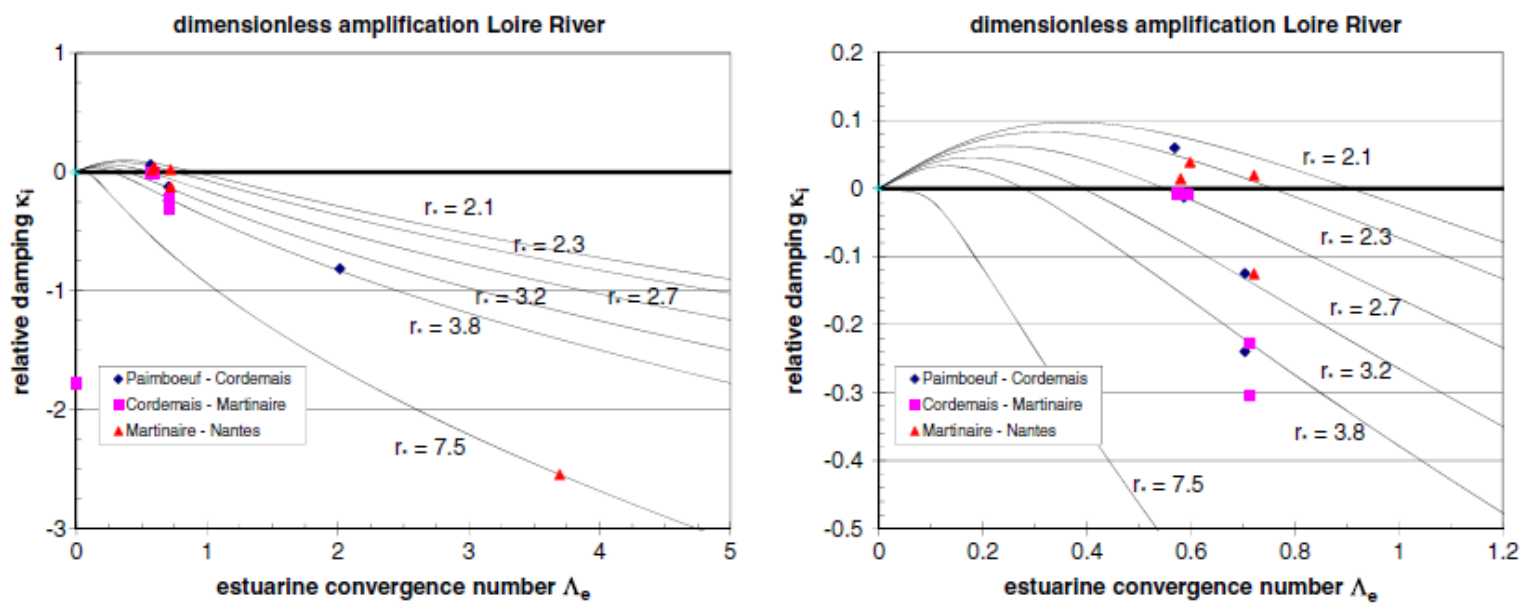

Fig.16 Tidal amplification as function of estuarine convergence number. (Left panel) contains all data, whereas (right panel) contains data after 1930 only

mixing) may be overruled by the effects of the river flow, inducing ebb dominance, flushing mud from the system. Indeed, Sogreah (2006) reports full flushing of the turbid water (or fluid mud) from the river at prolonged (>12 days) high river flows, e.g., around 2,000 $\mathrm{m}^{3} / \mathrm{s}$, conditions which may, however, not occur every year. According to anecdotal information, it takes a few weeks only after such flushing conditions to reestablish hyperturbid conditions. 


\section{Autorenfassung}

Winterwerp, Wang, van Braeckel, van Holland, Kösters: Man-induced regime shifts in small estauries-II: a comparison of rivers, 2013

\section{The Scheldt River-Belgium}

The Scheldt estuary is located in Belgium and The Netherlands and measures almost $200 \mathrm{~km}$, from its mouth along the North Sea to the weirs/sluices in Ghent. In Belgium, the river is known as the Lower and Upper Sea Scheldt; the Upper Sea Scheldt is fresh. The head of salinity intrusion migrates in the Lower Sea Scheldt with the tide and river flow. Large port developments took place along the Lower Sea Scheldt (Port of Antwerp). The freshwater flow varies between 30 and 300 $\mathrm{m}^{3} / \mathrm{s}$, with a long-term mean of about $120 \mathrm{~m}^{3} / \mathrm{s}$.

Because these large port developments hamper the use of the simple linear analytical model developed in Part I, the focus of this section is on the Upper Sea Scheldt from Schelle (kmr 91.2 from Flushing) to Melle (kmr 150.8 fromFlushing). The weir in Ghent lies about $8 \mathrm{~km}$ up-estuary of Melle.

Van Braeckel et al. (2006) summarize modifications in the Scheldt estuary. The majority of the engineering works in the Upper Sea Scheldt took place before 1900, e.g., rectifications of the river and embanking intertidal areas. In the early 1900s (1900-1930), parts of the river were normalized, and later, rectifications took place in the Durme. In the 1970s, the river deepened by 1.5-2 m, e.g., Fig. 18, though no major engineering works were carried out in this river section. Probably, this deepening was largely induced by the morphodynamic response to engineering works further down-estuary, such as sand mining and deepening and widening of the navigation channel in the Western Scheldt and Lower Sea Scheldt. Also, deepening and widening of the navigation channel in the Scheldt estuary down-estuary of Antwerp in the second half of the twentieth century and early twenty-first century must have had an effect on the tidal evolution, as discussed below (see also Kuijper and Lescinski 2012).

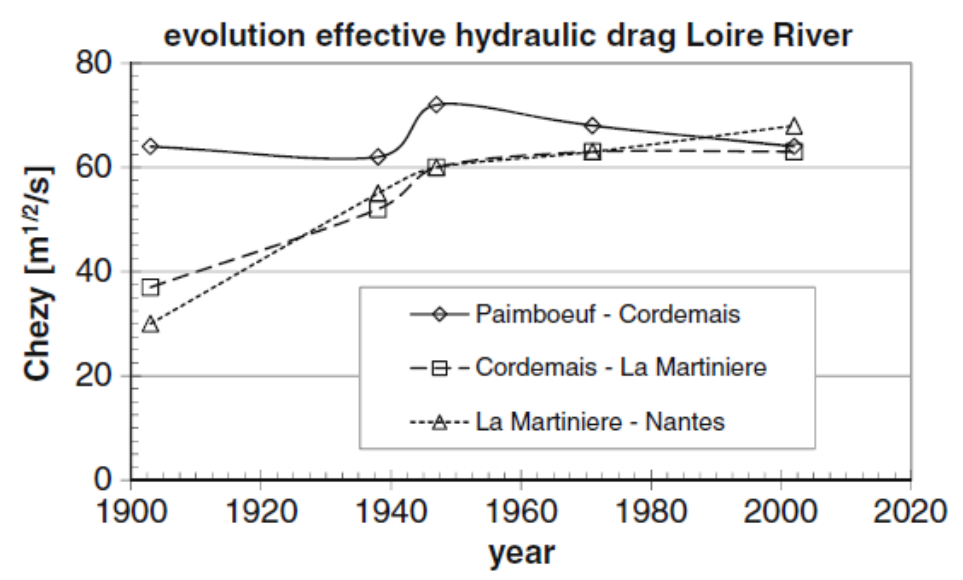

Fig. 17 Evolution of effective hydraulic drag Loire estuary-note that because of low accuracy of the tidal data, the error in this graph is relatively large 


\section{Autorenfassung}

Winterwerp, Wang, van Braeckel, van Holland, Kösters: Man-induced regime shifts in small estauries-II: a comparison of rivers, 2013

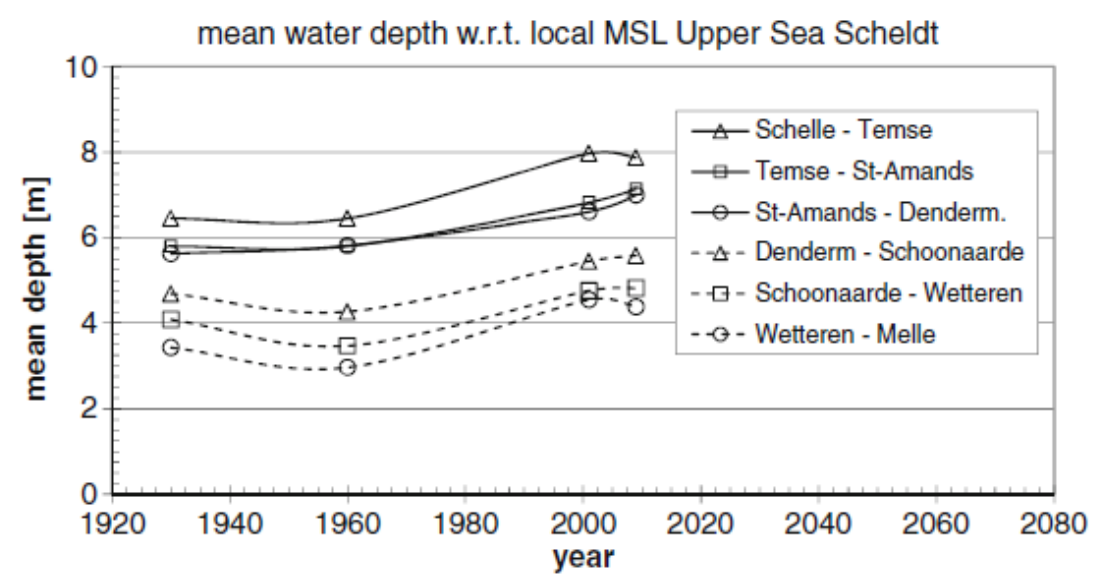

Fig.18 Evolution ofmean water depth between the various tidal stationsalong the Upper Sea Scheldt

Winterwerp, Wang, van Braeckel, van Holland, Kösters:

Man-induced regime shifts in small estauries-II: a comparison of rivers.

Zeitschrift Ocean Dynamics 63 (2013), S. 1293-1306.

The evolution of the water depth in the Upper Sea Scheldt is further elaborated in Fig. 18 showing the water depth with respect to local mean water level, based on data from IMDC (2012). The water depth in Fig. 18 is obtained from dividing the flow-carrying cross-sectional area by the width of the river and then averaging over the river sections in between the tidal stations.

At the head of the estuary, around Ghent, a number of engineering works were carried out between 1950 and 1970. These works consisted of the creation of a new channel of about $4 \mathrm{~km}$ length with a shipping lock for access to Ghent. Between around 1960 and 1970, the Upper Sea Scheldt became deeper, and the old northern arm of the Upper Sea Scheldt has silted up largely. This old Scheldt branch measured about $8.4 \mathrm{~km}$ from Melle tidal station to the weir in Ghent, whereas the new branch measures about $7.2 \mathrm{~km}$.

The convergence length of the Upper Sea Scheldt depicts a kink around km 124, i.e., between Dendermonde and Schoonaarde. In the lower $32 \mathrm{~km}$ of the Upper Sea Scheldt, Lb measures about $24 \mathrm{~km}$, and in the upper $28 \mathrm{~km}$ about $\mathrm{L}_{b}=36 \mathrm{~km}$, with some variations over time. Note that the river rectifications in the late nineteenth century must have reduced this convergence length by about $5 \mathrm{~km}$.

The width of the intertidal area shows a continuous decrease since 1850, in particular between 1850 and 1930 in the upper reaches of the river. Today, b* is small, measuring about 1.1, and has been small over most of the time of our analysis.

Tidal data for the entire Scheldt estuary are available from before 1900. Kuijper and Lescinski (2012) corrected these data for the 18.6-year cycle, the results of which are shown in Fig. 19 (e.g., 


\section{Autorenfassung}

Winterwerp, Wang, van Braeckel, van Holland, Kösters: Man-induced regime shifts in small estauries-II: a comparison of rivers, 2013

difference between high and low water). In the following, we focus on the Upper Sea Scheldt, i.e., up-estuary from Schelle. For an analysis of the time evolution of the entire estuary, the reader is referred to Kuijper (Kuijper and Lescinski 2012, Western Scheldt) and Plancke (Plancke et al. 2012, for Sea Scheldt).

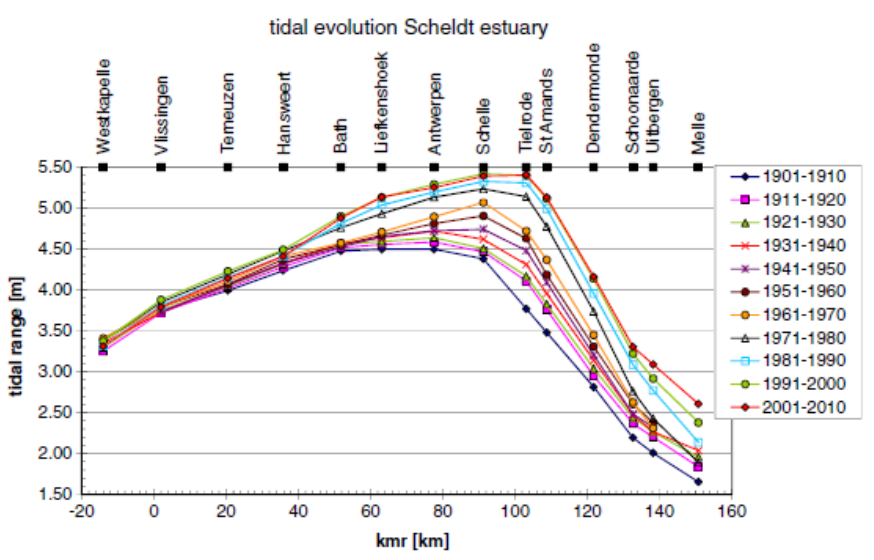

Fig. 19 Evolution of tidal range in Scheldt estuary, corrected for 18.6-year cycle

Figure 20 presents the imaginary wave number $\mathrm{k}$ i as derived from the measured tidal data of Fig. 19 , showing a number of important trends:

- From Schelle to halfway Dendermonde-Schoonaarde, the damping of the tidal wave increases (ki more negative), and beyond $\sim \mathrm{km} 125$, the damping decreases again.

- In general, the damping along most part of the river has decreased over time.

- Close to Schelle, the tidal wave is no longer damped in the early twenty-first century.

The change in longitudinal trend of the imaginary wave number beyond Dendermonde/Schoonaarde in Fig. 20 is remarkable, and we suspect that this trend is due to reflections of the tidal wave against the weirs around Ghent. To explore this further, we have computed the tidal amplitude along the river beyond Sint Amands without and with a weir $8 \mathrm{~km}$ upestuary of Melle. We have assumed a constant convergence length and a mean depth of $4.5 \mathrm{~m}$. The results are presented in Fig. 21 in the form of the difference in imaginary wave number $\Delta$ ki between the configuration with and without weir. Figure 21 shows a difference of about $0.005 \mathrm{~km}-1$, suggesting that the reverse in trend of Fig. 20 can indeed be explained by tidal reflections although the computed increase is about a factor two too small. Note that these results are not sensitive to the convergence length Lb, but highly sensitive to the water depth - the latter varies considerably over the last part of the river, whereas no information is available on the sections up-estuary of Melle. The results of Fig. 21 are therefore only indicative of the effect of tidal reflections on the tidal evolution.

Next, the imaginary wave numbers of Fig. 20 are made dimensionless with the convergence length of the Upper Sea 


\section{Autorenfassung}

Winterwerp, Wang, van Braeckel, van Holland, Kösters: Man-induced regime shifts in small estauries-II: a comparison of rivers, 2013

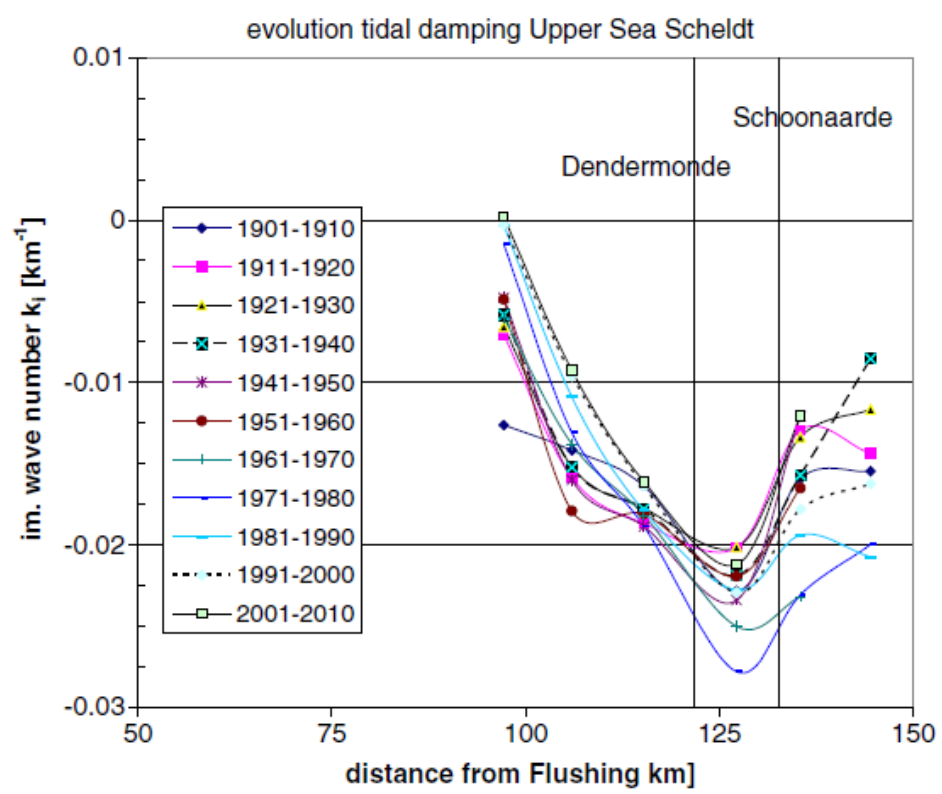

Fig. 20 Evolution of imaginary wave number along Upper Sea Scheldt, based on the data of Fig. 19

Winterwerp, Wang, van Braeckel, van Holland, Kösters:

Man-induced regime shifts in small estauries-II: a comparison of rivers.

S. 1303 Zeitschrift Ocean Dynamics 63 (2013), S. 1293-1306.

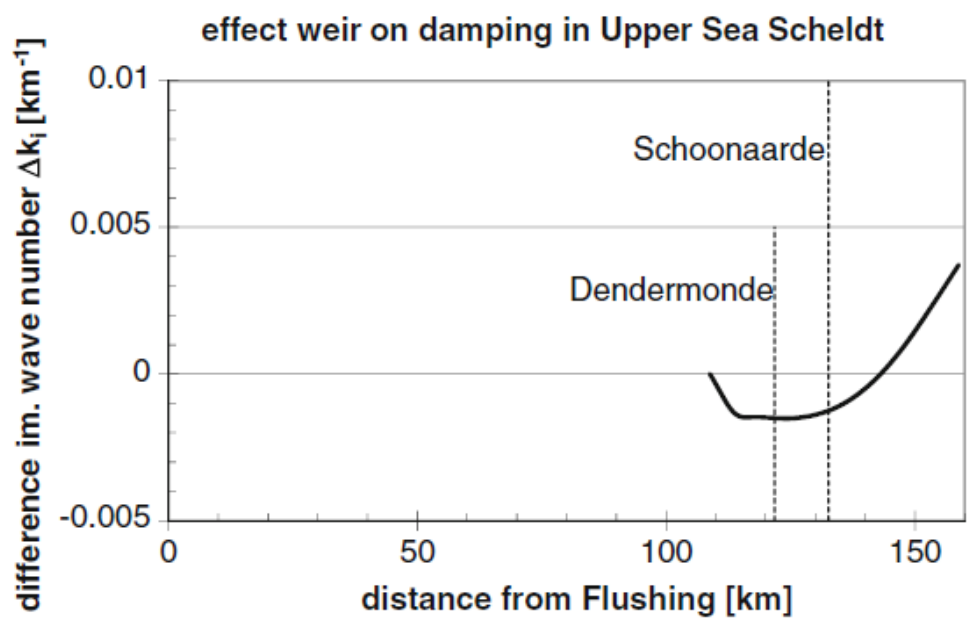

Fig. 21 Estimate of effect of weir on tidal damping in the upper reaches of Upper Sea Scheldt 


\section{Autorenfassung}

Winterwerp, Wang, van Braeckel, van Holland, Kösters: Man-induced regime shifts in small estauries-II: a comparison of rivers, 2013

Scheldt (e.g., equ. 9, Part I), where data up-estuary of Schoonaarde are omitted, as these are affected too much by tidal reflection. The dimensionless damping is plotted against the estuarine convergence number $\Lambda_{\mathrm{e}}$ in Fig. 22, showing the same trend in time as for the other rivers, i.e., time runs diagonally from the right-lower corner to the left-upper corner. Data from before the large deepening in the Upper Sea Scheldt $(<1960)$, data beyond 1990, and data in between have been marked with different colors. In particular, the data for the trajectory Dendermonde-Schoonaarde are a bit erratic (results not shown), most likely because of the effects of tidal reflection, and therefore not further included in our analysis.

Next, the linear model for an infinitely long tidal river (equ. 10b, Part I) is fitted through the data by tuning the roughness parameter $r$, the results ofwhich are also presented in Fig. 22, showing reduction in $r$ from 9 to about 3.

To compute the effective hydraulic drag from the fitted $r$ * values, we use again the amplitude of the flow velocity from equ. (12) (Part I) and the measured tidal amplitudes. The computed variation of $\mathrm{C}$ with time along the lower part of the Upper Sea Scheldt is presented in Fig. 23. All Chézy values are a bit low, which may be attributed to the fact that in the linear model many physical features in the river (bends, bed forms, bank irregularities, local variations in river topography and bathymetry, etc.) are missing.

Yet, Fig. 23 suggests that the effective hydraulic drag, hence the Chézy coefficient, did not change in the river stretch St Amands-Dendermonde, but increased considerably over the first part of Schelle-Temse. If this reduction in drag would have been caused by high suspended sediment concentrations, this analysis suggests that values in SPM have been large for many decades, which, in conjunction with the deepening in the 1960s/1970s (e.g., Fig. 18), may explain the increase in C. The anomalous behavior between 1980 and 1990 is not understood, but may be misleading, as topographic/ bathymetric data over that period is missing and had to be created by interpolation of data from other decades (see also bed level data of Fig. 18).

Indeed, SPMvalues have been reported to be fairly large at about $200 \mathrm{mg} / \mathrm{l}$ over a long stretch of the river up to km 100 (Temse). Unfortunately, no historic SPM data exist, and it is therefore not possible to relate the results of Fig. 23 to such data.

Figure 24 presents measured data on tidal asymmetry, in the formof the ratio of the period of rising tide and falling tide, showing pronounced flood dominance over the entire river (Plancke et al. 2012). It is observed that flood dominance increases in the upstream direction, as expected, as water depth decreases in the upstream direction. We note that the river's freshwater flow is relatively small and hence only slightly affects the duration of the flood and ebb period.

However, it is remarkable that the asymmetry changes little over time, except maybe for Schelle, given the large increase 


\section{Autorenfassung}

Winterwerp, Wang, van Braeckel, van Holland, Kösters: Man-induced regime shifts in small estauries-II: a comparison of rivers, 2013

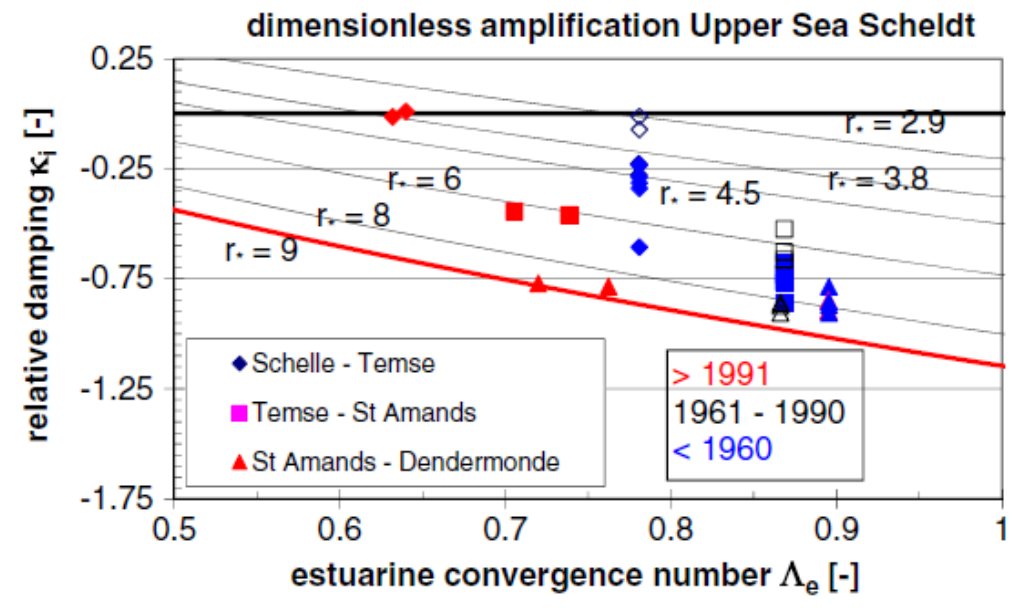

Fig. 22 Fits of linear solution trough observations tuning the roughness parameter $\mathrm{r}^{*}$ in the $\kappa_{\mathrm{i}-}$ $\Lambda_{\mathrm{e}}$ diagram

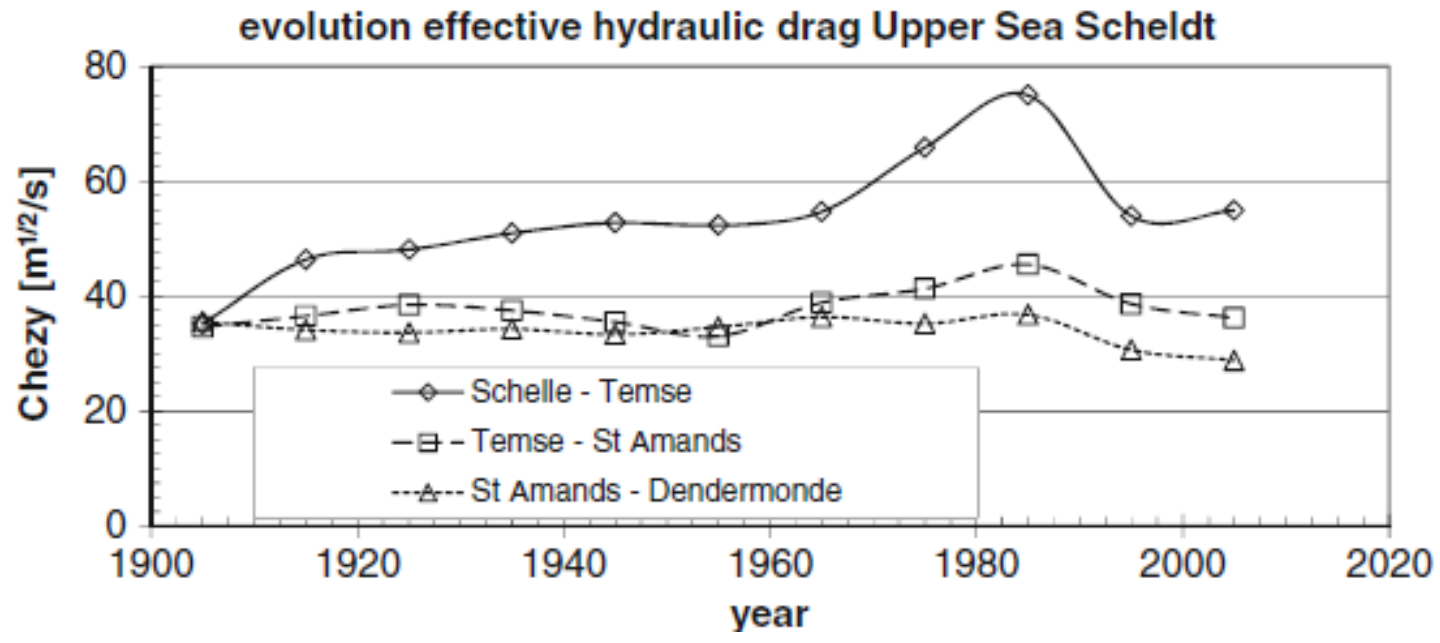

Fig. 23 Evolution of effective hydraulic drag (Chézy coefficient) with time 


\section{Autorenfassung}

Winterwerp, Wang, van Braeckel, van Holland, Kösters: Man-induced regime shifts in small estauries-II: a comparison of rivers, 2013

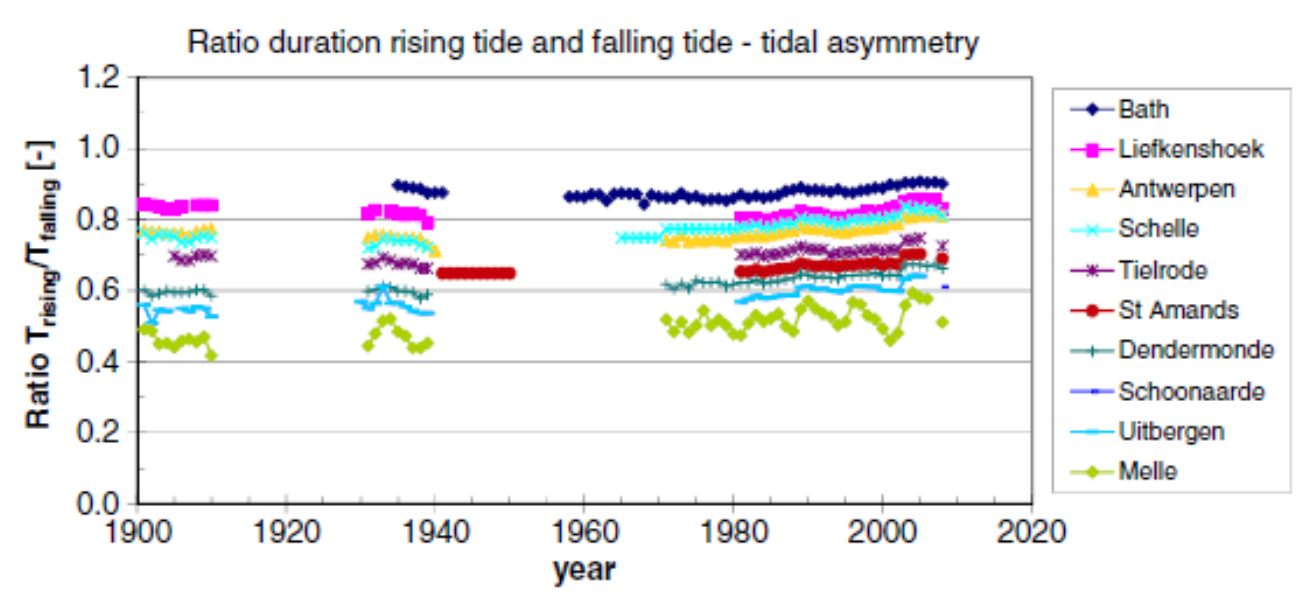

Fig. 24 Observed tidal asymmetry in Sea Scheldt

Winterwerp, Wang, van Braeckel, van Holland, Kösters:

Man-induced regime shifts in small estauries-II: a comparison of rivers.

Zeitschrift Ocean Dynamics 63 (2013), S. 1293-1306.

in tidal amplitude. This discrepancy can be explained from two counteracting developments:

- In particular in the upper reaches, the water depth has increased largely in a relative sense. Larger water depth would decrease tidal asymmetry, counteracting the effects of a larger tidal range.

- Probably more important is the development of tidal asymmetry in the Western Scheldt, e.g., Fig. 24, which serves as "boundary conditions" for the Upper Sea Scheldt. Hence, further to the local generation of overtides in the Upper Sea Scheldt, tidal asymmetry is "imported" from the down-estuary reaches of the estuary, i.e. the Western Scheldt. Wang et al. (2002) showed that the flood dominance at Bath, the most upstreamstation in the Western Scheldt, has been decreasing in time.

It is beyond the present study to evaluate the evolution of tidal asymmetry in the Western Scheldt, but the behavior of the asymmetry at Hansweert is remarkable, suggesting that its asymmetry tends to reestablish the conditions at the beginning of the twentieth century.

\section{Discussion, summary, and conclusions}

In the 20th century,many European rivers have experienced large amplification of the tide, often with enormous environmental consequences. In this paper, and the accompanying Part I, we have analyzed the historical development of these amplifications in four tidal rivers with the aim of un- 


\section{Autorenfassung}

Winterwerp, Wang, van Braeckel, van Holland, Kösters: Man-induced regime shifts in small estauries-II: a comparison of rivers, 2013

derstanding their response to human interferences. This analysis of the data is carried outwith a linear analytical model, solving the shallow water equations, e.g., Part I. The tidal amplification in these rivers can be characterized by a dimensionless imaginarywave number $\kappa_{\mathrm{i}}$, as a function of the estuarine convergence number $\Lambda_{\mathrm{e}}$, and a dimensionless friction coefficient $r^{*}$ - the latter decreases with decreasing effective hydraulic drag. $\Lambda_{\mathrm{e}}$ decreases with increasing water depth, decreasing convergence length (increase in tapering) and decreasing intertidal area.

Using these dimensionless numbers, the tidal evolution of estuaries can be compared mutually. The friction coefficient $r^{*}$ is established by calibration of the analytical model through the data, assuming an infinitely long estuary (e.g., no reflections). The rivers have been divided into subsections, following available bathymetrical data and tidal stations. The results of this comparison are presented in Fig. 25, where the temporal evolution runs along a diagonal from the lower-right corner to the upper-left corner. Each data point reflects the tidal amplification in a specific river section over a certain period of time. The analytical model predicts that, within the range of relevant values, e.g., Fig. 25, a decrease in $\Lambda_{\mathrm{e}}$ induces amplification of the tide (or, more precisely, a reduction in the amount of damping), or in other words, $\kappa_{\mathrm{i}}$ increases. Further to this response in tidal amplification, the river becomes flooddominant for small intertidal areas(e.g., Part I). However, the sensitivity of $\kappa_{\mathrm{i}}$ to variations in $\Lambda_{\mathrm{e}}$ around $\Lambda_{\mathrm{e}}=1-2$ at small $\mathrm{r}^{*}$ is small (e.g., Fig. 6, Part I). From a practical point of view, this implies that for such conditions it will not be easy to reduce the tidal amplification by interventions in the river.

This analytical picture is corroborated grossly by the data. Figure 25 shows that all rivers, except the outer Elbe, depict a decrease in $r$ * while $\Lambda_{\mathrm{e}}$ decreases as a result of engineering works. The decrease in $r^{*}$ from 7 to 0.8 implies an increase in Chézy coefficient from about 40 (e.g., a sandy bed with bed forms) to about $90 \mathrm{~m}^{1 / 2} / \mathrm{s}$ (e.g., a very muddy environment).

In detail though, the rivers have different stories. The Ems and Lore Rivers are infamous for their very large suspended sediment concentrations (several $10 \mathrm{~g} / \mathrm{l}$ ) and occurrences of fluid mud. From the analyses in Part I, it is hypothesized that both rivers have passed a tipping point, evolving into their current hyperturbid state following a positive feedback between tidal amplification, flood dominance, and up-estuary transport of fine sediment. At that state, frictional effects are very small because of sediment-induced buoyancy destruction (e.g., Winterwerp 2011), and the tide becomes highly sensitive to bathymetrical and geometrical changes (e.g., Jay 1991). At high SPM values, the hyperturbid conditions become self-maintaining, as these conditions are favorable from an energy point of view-the river has migrated towards an alternative steady state.

Moreover, the tidal amplification in the Ems is affected by reflections against the weir at Herbrum. The effects of such reflections increase with decreasing effective hydraulic drag, as the friction length increases rapidly. 


\section{Autorenfassung}

Winterwerp, Wang, van Braeckel, van Holland, Kösters: Man-induced regime shifts in small estauries-II: a comparison of rivers, 2013

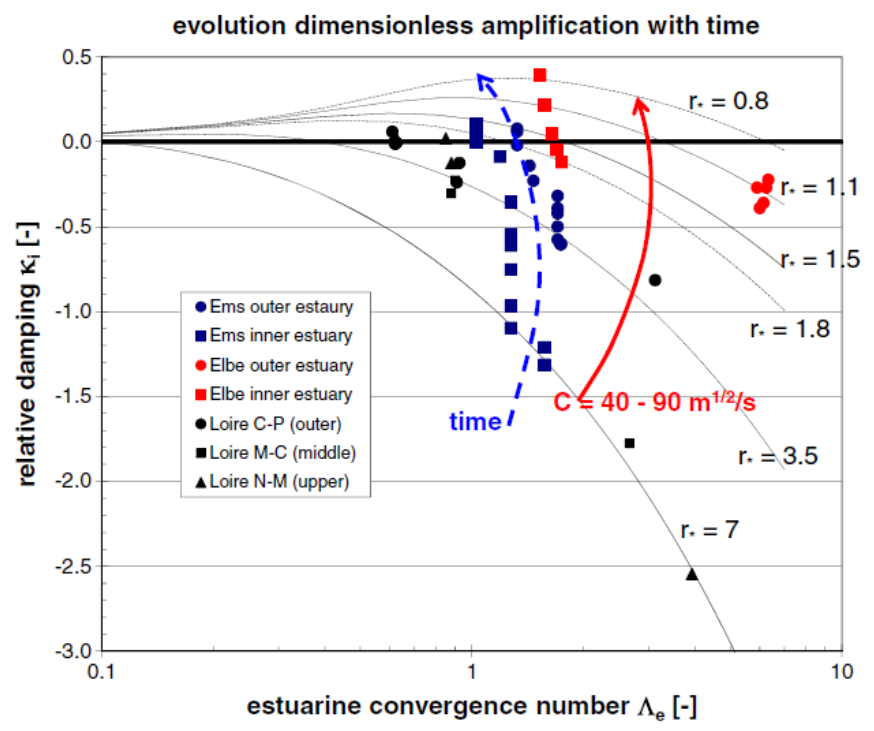

Fig. 25 Comparison of tidal evolution in four European rivers. In the course of time, $\Lambda$ e decreased continuously, inducing ki to increase. Note that data for the inner Elbe aremisleading, as there are indications that the tidal evolution in the Elbe is affected more by reflections than by high suspended sediment concentrations

Winterwerp, Wang, van Braeckel, van Holland, Kösters:

Man-induced regime shifts in small estauries-II: a comparison of rivers. Zeitschrift Ocean Dynamics 63 (2013), S. 1293-1306.

In Part I, it was argued that the tide in estuaries becomes very sensitive to deepening after loss of intertidal area: with that loss, the resilience of the estuaries decreased. This sensitive response is well depicted by the tidal evolution in the Loire upon the large narrowing of the river in the early twentieth century.

The tidal range in the Sea Scheldt in the vicinity of Antwerp and the lower part of the Upper Sea Scheldt has increased by about $1 \mathrm{~m}$. In particular, the large amplification in the Upper Sea Scheldt is remarkable, as locally no large-scale engineering works took place in the twentieth century. Yet, the river deepened by 1-2 m over considerable lengths. We have indications that this deepening likely reflects the morphodynamic response of the estuary to large-scale deepening and widening of the navigation channel in the river further down-estuary, and the large-scale sand extraction (about $250 \mathrm{Mm}^{3}$ of sediment has been removed from the Scheldt estuary since 1955). In the lower part of the Upper Sea Scheldt, e.g. up-estuary of the head of salinity intrusion, SPM values are now increasing to several $100 \mathrm{mg} / \mathrm{l}$, which may explain the decrease in effective hydraulic roughness, established with the linear analytical model. This increase, beyond the salinity intrusion, is likely to be attributed to the strong flood dominance of the tide, in conjunction with a reduction in flushing capacity of the river. 


\section{Autorenfassung}

Winterwerp, Wang, van Braeckel, van Holland, Kösters: Man-induced regime shifts in small estauries-II: a comparison of rivers, 2013

The tide in the upper $25 \mathrm{~km}$ of the Upper Sea Scheldt is affected by reflections of the tidal wave against the structures erected around Ghent.Currently, the riverbed is sandy, and the tide damped. It is anticipated that the tidal amplification in general, and the impact of tidal reflections in particular, will increase rapidly if the SPM concentrations in the Upper Sea Scheldt would increase further, as the roughness length Lr reduces with increasing SPM values. Currently, it cannot be established whether or not the Sea Scheldt is approaching a tipping point towards hyperturbid conditions.

The plan form of the Elbe has been modified largely, and the fairway was deepened bymanymeters. In the lower part of the Elbe, SPM concentrations are quite large, and we established a fairly low effective hydraulic drag, consistent with information from German colleagues. However, SPM concentrations in the upper part of the Elbe are low, owing to the sediment management around the Port of Hamburg.The strong increase in tidal range in this part of the river is likely to be attributed to (partial) reflections of the tidal wave against the large step in river depth in Hamburg.

The effects of tidal reflections can only be studied qualitatively with the linear analytical model, whereas the effects on (variations in) river flow cannot be studied. Yet, from the data, it can be concluded that, for instance, the tide in the Ems' section between Papenburg and Herbrum is strongly affected by the river flow, even though this flow is quite small. More advanced models, accounting for nonlinear effects and detailed bathymetrical features, are required to analyze the effects of tidal reflections and river flow in further detail; this is the subject of further work. In spite of the limitations of the current analyses, and the differences in the details of the temporal evolutions of the various rivers, a number of general conclusions can be drawn from the analytical study in Part I, and the data analysis of Part II of our paper:

- The observed amplification of the tide in the four rivers cannot be explained from geometrical/bathymetrical changes in these rivers alone.

- The loss of intertidal area from these tidal rivers has reduced their resilience to further engineering works (e.g., deepening) largely; also, accommodation space for suspended fine sediments has been lost. This loss in resilience took place in the late nineteenth and early twentieth centuries, whereas further engineering works took place in the second half of the twentieth century.

- The interaction of suspensions of fine sediments with the tidal movement may set in motion a positive feedback loop through a reduction in effective hydraulic drag. Then, large amounts of fine sediments may be pumped into the river owing to their flood dominance. The alternative, hyperturbid state towards which the river may develop is very stable and self-maintaining.

- In some rivers, the tide is affected by reflections against constructions in the river-such effects become more prominent with decreasing effective hydraulic drag. This is particularly the case for the upper part of the Elbe River. 


\section{Autorenfassung}

Winterwerp, Wang, van Braeckel, van Holland, Kösters: Man-induced regime shifts in small estauries-II: a comparison of rivers, 2013

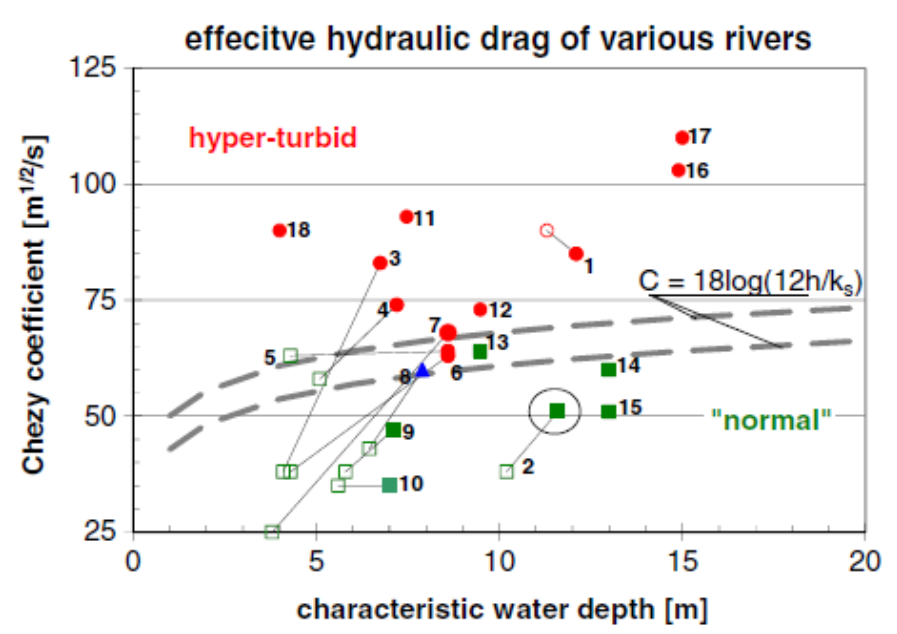

Fig. 26 Comparison of effective hydraulic drag in some rivers as a function of water depth. The $\mathrm{C}-\mathrm{h}$ relation is based on $\mathrm{k}_{\mathrm{s}}=2$ and $5 \mathrm{~cm}$, arbitrary values. Red symbols depict hyperturbid conditions; green symbols, "normal" conditions; and blue symbols, possibly transitional systems; open symbols reflect historical data. 1 Elbe-outer, 2 Elbe-inner, 3 Ems/E-L, 4 Ems/L-P, 5 Loire/P-C, 6 Loire/C-laM, 7 Loire/LaM-N, 8 Scheldt/S-T, 9 Scheldt/T-StA, 10 Scheldt/StA-D, 11 Thames, 12 Severn-inner, 13 Severn-outer, 14 Western Scheldt, 15 Gironde-outer, 16 Girond e-inner (Villaret et al. 2011), 17 Yangtze estuary, 18 Vilaine (Vested et al., 2013). Note that data on Elbe-inner may be spurious because of tidal reflections, as discussed in Section 2

Winterwerp, Wang, van Braeckel, van Holland, Kösters:

Man-induced regime shifts in small estauries-II: a comparison of rivers.

S. 1306

Zeitschrift Ocean Dynamics 63 (2013), S. 1293-1306.

It is noted that the behavior of the Ems and Loire River is not unique. Other rivers have beenlargely engineered as well, whereas also a number of more or less "pristine" rivers (Severn, Yangtze ${ }^{1}$ ) are also characterized by hyperturbid conditions. Figure 26 summarizes values of Chézy coefficients for a number of rivers (and their subsections) as a function of the water depth, depicting the SPM state of these rivers by the color of the symbols. It is well known that hyperturbid rivers are characterized by high $C$ values. Possibly, the evolution of effective hydraulic roughness may indicate whether a river approaches its tipping point at which a positive feedback loop sets in motion the river's development towards hyperturbid conditions. The "normal" $\mathrm{C}-\mathrm{h}-\mathrm{k}_{\mathrm{s}}$ relation (Fig. 26) may serve as a reference for this analysis. Further work is required to elaborate on this diagram and to account for the effects of river flow and tidal reflections. The data suggest that the development of hyperturbid

\footnotetext{
${ }^{1}$ We realize that the Yangtze is not pristine; however, the high SPM values occurred well before the various large-scale interventions in the river and its catchment.
} 


\section{Autorenfassung}

Winterwerp, Wang, van Braeckel, van Holland, Kösters: Man-induced regime shifts in small estauries-II: a comparison of rivers, 2013

conditions upon passing a tipping point may take one to two decades. The availability of fine sediments is probably a limiting factor in this.

Finally, it is emphasized that a full understanding of the tidal evolution in these rivers, in conjunction with the sediment dynamics (SPM values, morphodynamic response), requires hind-cast simulations of these developments with advanced numerical models, integrating hydrodynamics, morphodynamics, and fine sediment transport. Until then, the analyses presented in this paper remain hypothetical.

\section{Acknowledgments}

This work was carried within the framework of the LTV project, which is the acronym for the LongTerm Vision of Scheldt estuary with respect to Safety, Accessibility and Nature, in which the following subprojects are integrated:Maintaining fairways Scheldt estuary, Permits for disposal of dredged sediments and the so-called KPP (knowledge of primary processes) program of Rijkswaterstaat. The study was financed by the Flemish "Afdeling Maritieme Toegang" (Maritime Department) and Rijkswaterstaat,Waterdienst, and Directorate Zeeland (the Dutch Ministry of Infrastructureand Environment). The subject of the research in this paper was formulated by Mr. Youri Meersschaut requesting the analysis of the fine sediment dynamics in the Scheldt River. Further, we like to thank Dr. Henk Schuttelaars for his many constructive comments and ongoing discussions on this subject, and Dr. Tom de Mulder for reviewing an earlier report of this study.We also would like to acknowledge the help of Mr. Marcel Taal in organizing and coordinating our study.

The results in this paper are based on a large number of data from a variety of sources. Some data sets were available at Deltares in reports, or in digital form from studies carried out earlier. Other data have been prepared and madeavailable especially for this project.We would like to thank the following people for their support and supply of data: Mr. Frederik Roose (Flemish Government) for Scheldt data; Dr. Luc Hamm (Sogreah) for information on the Loire; Dr. Harro Heijer and Mr. Jens Jürges (BAW) for data on the Ems, Weser, and Elbe river; and Prof. Ian Townend for data on the Thames and Severn estuaries. Furthermore, Dr. Holger Weilbeer (BAW) and Dr. Jens Kappenberg (Helmholz Centre) were helpful in some discussions on the Elbe and Ems Rivers.

\section{References}

BAW (2012) Data received from Dr. Frank Kösters and Jens Jürges on Ems and Elbe

Briere C, Crebas J, Becker A, Winterwerp J.C (2012) Analyse de la morphologie du chenal de Nantes et étude de sa restauration - Phase 3 : Etude de l'impact d'une intervention à l'amont de Nantes sur les caractéristiques de la marée. Deltares report 1201695 (in French) 


\section{Autorenfassung}

Winterwerp, Wang, van Braeckel, van Holland, Kösters: Man-induced regime shifts in small estauries-II: a comparison of rivers, 2013

de Jonge VN (2000) Importance of temporal and spatial scales in applying biological and physical process knowledge in coastalmanagement, an example for the Ems Estuary. Cont Shelf Res 20:1655-1686

Herrling G, Niemeyer HD (2008) Comparison of the hydrodynamic regime of 1937 and 2005 in the Ems-Dollard estuary by applying mathematical modeling. Research project: INTERREG IIIB North Sea project HARBASINS; Work package 4: "Hydro-morphological impacts and pressures" Lower Saxony Water Management, Coastal Defense and Nature Conservation Agency, Coastal Research Station

IMDC (2012) Analyse bodemgegevens Boven Zeeschelde. Note I/NO/11387/12.226/VBA

Jay DA (1991) Green law revisited: tidal long-wave propagation in channels with strong topography. J Geophys Res 96(C11):20,585-20,598

Kappenberg J, Fanger H-U (2007) Sedimenttransportgeschehen in der tidebeeinflussten Elbe, der Deutschen Bucht und in der Nordsee. GKSS report 2007/20; ISSN 0344-9629

KrebsM,Weilbeer H (2005) Ems-Dollart estuary. Die Küste 74:252-262

Kuijper C, Lescinski J (2012) LTV Veiligheid en Toegankelijkheid. Sub project B: Data analysisWestern Scheldt. Report 1204405. Deltares

Plancke Y, Maximova T, Ides S, Peeters P, Taverniers E, Mostaert F (2012) Werkgroep O\&M - Projectgroep Veiligheid. Sub project 1: Data analysis and hypothesis - Upper Sea Scheldt. Report WL2012R756_05_rev4_0. Flanders Hydraulics Research

Schrottke K, Bartholomä A (2008) DetaillierteEinblicke in die ästuarine Schwebstoffdynamik mittels hochauflösender Hydroakustik. Tagungsband zum Seminar Ultraschall in der Hydrometrie: neue Technik; neuer Nutzen; FgHW / DWA, Koblenz, June 2008, 75-82

Sogreah (2006). Expertise et connaisssance du systeme estuarien de Loire - Tome 1: Analyse historique, Report 1711457R2

Talke SA, de Swart HE, de Jonge VN (2009) An idealized model and systematic process study on oxygen depletion in highly turbid estuaries. Estuar Coasts 32(4):602-620

Van Braeckel A, Piesschaert F, van den Bergh E (2006) Historische analyse van de Zeeschelde en haar getijgebon den zijrivieren. 19e eeuw tot heden. INBO report INBO.R.2006.29 


\section{Autorenfassung}

Winterwerp, Wang, van Braeckel, van Holland, Kösters: Man-induced regime shifts in small estauries-II: a comparison of rivers, 2013

Van Rijn LC (1993) Principles of sediment transport in rivers, estuaries and coastal seas. AQUA Publications, The Netherlands

Vested HJ, Tessier C, Goubert E (2013) Numerical modeling of morphodynamics-Vilaine Estuary. Ocean Dyn 63:423-446

Villaret C, Huybrechts N, Davies AG, Way O (2011) Effect of bed roughness prediction on morphodynamic modelling: application to the Dee estuary (UK) and to the Gironde estuary (France). Proceedings 34th IAHRWorld Congress-Balance and Uncertainty, Brisbane, Australia: 1149-1156, ISBN 978-0-85825-868-6

Vroom J, van den Boogaard H, vanMaren B (2012) Mud dynamics in the Eems-Dollard, research phase 2-analysis of existing data. Deltares, report 1205711-001

Weilbeer H, Klöpper M, Bundesanstaltfür Wasserbau (2011) Model validation and system studies for hydrodynamics, salt and sediment transport in the Elbe Estuary-basic information for the river engineering and sediment management. Draft Report A39550310069

Wang ZB, Jeuken C, Gerritsen H, de Vriend HJ, Kornman BA (2002) Morphology and asymmetry of vertical tide in the Western Scheldt Estuary. Cont Shelf Res 22(17):2599-2609

Winterwerp JC (2011) Fine sediment transport by tidal asymmetry in the high-concentrated Ems River: indications for a regime shift in response to channel deepening. Ocean Dyn 61(23):203-215 